\title{
Bats of the Prespa Basin in northern Greece: acoustic survey, new records and relationships to light pollution (Chiroptera)
}

Netopiere Prespanskej kotliny v severnom Grécku: akustický prieskum, nové údaje a vzt’ahy k svetelnému znečisteniu (Chiroptera)

\author{
Marcel UHRIN ${ }^{1}$, Monika BALOGOVÁ ${ }^{1}$, Romana UHRINOVÁ \& Viktória VARGOVÁ ${ }^{1}$ \\ ${ }^{1}$ Institute of Biology and Ecology, Faculty of Science, P. J. Šafárik University, Moyzesova 11, \\ SK-040 01 Košice, Slovakia; marcel.uhrin@gmail.com \\ ${ }^{2}$ WWF Slovakia, Medená 101/5, SK-811 02 Bratislava, Slovakia
}

received on 5 December 2020

\begin{abstract}
The bat survey in the Greek part of the Prespa basin in 2018-2020 confirmed, despite the limited methods used, its extraordinary importance for bat diversity. The study documented the presence of 22 bat forms ( 20 species) by acoustic surveys and a favourable status of some roosts including several nursery colonies. Three of the recorded species are here reported for the first time, Eptesicus nilssonii (the first record for Greece), Nyctalus lasiopterus, and Barbastella barbastellus, however, confirmation by a capture or direct observation of an individual is still needed. The collected data showed that bats do not avoid the urbanized parts of the study area and underlined the importance of old houses, churches, and ruins providing suitable roosting and foraging opportunities. The measurements of light pollution in villages revealed a high amount of light diffusion caused by the used type of shieldless luminaires. Heat maps of light intensity revealed a slightly higher bat activity in almost all villages in 2020, upon the situation in 2018. Bat passes were recorded not only in the peripheries of the highest illumination zones but also inside them, although some of the bat passes may belong to bats flying enough in the dark above the light levels of the installed lamps. The study provides application of mitigation actions for the Municipality of Prespa with the main aim to reduce the current level of the ALAN (Artificial Light At Night).
\end{abstract}

Key words. Acoustic survey, Balkans, bats, fauna, Greece, light pollution, Mediterranean, Prespa region.

\section{INTRODUCTION}

The Prespa region, situated in the borderlands of three countries (Albania, Greece, and North Macedonia) is represented mainly by two natural lakes, Mikri Prespa and Megali Prespa surrounded by, mostly mountainous, limestone and granite landscapes. In general, the region hosts extraordinary biodiversity with high species numbers in almost all plant and animal groups, including large proportions of endemic species; these values are supported by well preserved cultural heritage and regional traditions (see e.g., BousBouras \& IOANNIDIs 1994, CATSADORAKIS 1999, 2002, Crivelli \& Catsadorakis 1997, Standring 2009, Strid et al. 2017, etc.). As a result, the Transboundary Prespa Park was established in 2000 as the first such protected area in the Balkans; parts of the Prespa region are also included in the Natura 2000 network of protected areas and the Mikri Prespa Lake is a Wetland of International Importance under the Ramsar Convention. 
Within the territory of this region, high diversity of bats was also documented -31 species altogether (e.g., von Helversen \& Weid 1990, Uhrin et al. 1996, Hanák et al. 2001, Gremillet et al. 2010, ThÉou et al. 2015a, b, ThÉou 2016, Micevski et al. 2014, Presetnik 2015, Galand et al. 2010, PAPADATOu et al. 2011, 2012, 2013, Benda et al. 2019). The first data on bats from the Greek part of the Prespa region were provided in the 1980s and 1990s by CATSADORAKIS $\&$ Kollaros (1986) and CATSADORAKIS (1995). They reported up to eight bat species occurring in the region (Rhinolophus ferrumequinum, R. hipposideros, Myotis daubentonii, M. nattereri, Nyctalus leisleri, Pipistrellus nathusii, P. pipistrellus s.1., and Tadarida teniotis). In parallel with that, a German zoologist Otto vON HELVERSEN visited the area a few times between 1981 and 1990 (and later also in 2007), but only a part of his bat data were published - records of Myotis daubentonii, M. nattereri, and Pipistrellus nathusii from August 1987 and August 1988 (von Helversen \& Weid 1990, Papadatou et al. 2011). Later on, several new bat records from the region made in July 2000 and September 2001 (Rhinolophus ferrumequinum, R. hipposideros, $R$. euryale, $P$. pipistrellus, and Plecotus austriacus) were included in the only comprehensive review of the Greek bat fauna (HANÁK et al. 2001). In the early 2000s, Xavier GRÉMILlet from the Groupe Mammalogique Breton (France) visited the Prespa region and revealed the importance of rock cavities for horseshoe bats (Rhinolophus sp.) and bent-winged bats (Miniopterus schreibersii); several expeditions to the region were thus organised in the period 2004-2011, in collaboration with Yannis Kazoglou from the Society for the Protection of Prespa (SPP). These expeditions applied all available survey methods - roost checks (natural and man-made), netting, acoustic survey, resulting in an increase of the number of bat species confirmed to occur in this part of the Prespa region to 26 (Gremillet \& Boireau 2004, Gremillet \& Dubos 2008, GREMILlet et al. 2010).

Later on, in 2009, the SPP launched a transboundary project aimed at the completion of a "Conservation Action Plan for the Bats of Prespa". This also resulted in an official transboundary cooperation of the researchers from Greece, Albania, and North Macedonia, within the framework of a development of the "Transboundary Monitoring System in the Prespa Park Area" (PerenNou et al. 2009) followed by bat surveys and surveys of bat roosts conducted in all three countries during the summer and autumn of 2010 and winter of 2011 (PAPADATOU et al. 2010, 2011). The picture of bat diversity and bat distribution was subsequently supplemented by (mostly acoustic) bat surveys of mountain ranges in the wider vicinity of the Prespa re- gion, i.e., in the Varnous and Triklarion Mountains (GALAND et al. 2010, VRahnakis et al. 2010, Papadatou et al. 2011, 2013).

Respecting the extraordinary high natural and cultural diversity of the region, the SPP conducted the project "Integration of Photovoltaic Plants for Self-consumption under the Net Metering Concept in Public Buildings/Pumping Stations and Replacement of Low-Efficiency Municipal/ Street Lighting with LED Lights" co-funded by the European Union and national funds of the participating countries in the framework of the Interreg IPA CBC Programme "Greece-Albania 2014-2020". The main issue of the project is the application of photovoltaic stations into the public infrastructure and the substitution of traditional public lighting with energy efficient and nature more friendly LED lighting fixtures. Among objectives of the project, the nature friendly modification of existing lighting fixtures was proposed for the ecologically sensitive area of the Prespa lakes, thus, the light pollution mitigation with the aim to enhance the conservation of fauna in the respective region with particular emphasis on bats was conducted. This approach is in concordance with recommendations revealed from a review of conservation efforts in the whole transboundary Prespa region (BRAJANOSKA et al. 2017). Thus, in order to assess the light 
pollution mitigation measures on various bat species, two types of surveys were carried out, bat survey (roosts and activity) and lighting survey. The surveys are important (a) to identify the key sites which are used by bats for foraging and commuting near the selected villages in the region, and (b) to determine the spatial extent of bat use over a site and assess changes in bat activity in villages selected for monitoring where interventions are planned (BACI - Before-After-Control-Impact). The basic background why light pollution should be considered in landscape planning is that the Artificial Light At Night (ALAN) causes many deviations from natural patterns of biological and ecological features of many organisms, including bats (for a review see e.g., Arlettaz et al. 2000, Rich \& LongCore 2006, Boldogh et al. 2007, Stone et al. 2009, 2015, HöLKER et al 2010, Davies et al. 2012, 2013, 2015, BenNie et al. 2015, Gaston et al 2014, 2015, Aubé 2015, Longcore et al. 2015, Dominoni et al. 2016, Rowse et al. 2016, LewanziK \& Voigt 2017, Azam et al. 2018, Souman et al. 2018, SAnders et al. 2020). Concerning bats, the main effects of the ALAN include (1) alteration of foraging behaviour, (2) increased risk of mortality in light barriers and/or in roosts, (3) reduction of night activity, (4) deteriorization of the roost quality, and (5) impacts on food resources and food chains (e.g., Zagmajster et al. 2014, Voigt \& Kingston 2016, van Langevelde et al. 2018, Rydell et al. 2017, VoigT et al. 2017, 2018a, b).

The aim of the presented report is to provide data on the bat occurrence and activity and on the related light pollution in the Prespa basin as revealed by the surveys conducted in the period 2018-2020 and by previously published sources.

\section{MATERIAL AND METHODS}

\section{Study area}

The study area represents the Greek part of the Prespa region and includes the southern part of the Megali Prespa Lake and the Mikri Prespa Lake with surroundings. It is delimited by the state border in the west and north, and by an approximate line between the villages of Krystallopigi, Andartiko, Karyes, Lefkonas, Lemos, and Agios Germanos in the east and south (Fig. 1).

\section{Data collection}

During the study, two survey elements were implemented: (1) bat surveys and (2) light pollution surveys. Bat surveys included (a) roost inspections, (b) acoustic monitoring of bat activity in selected villages and/or stationary recordings, and (c) car-based acoustic monitoring of bat activity on transects within the study area. During the study, altogether 24 acoustic surveys (with the total transect length of $443 \mathrm{~km}$ ) were conducted in 2018,2019, and 2020, eleven of them were car-based transects, ten walk and/or slow car driving in all priority selected villages, and three stationary recordings (Table 1).

Roost surveys were carried out within the whole study area with the aim to cover all possible sites that can be used by bats (old abandoned buildings, churches, ruins, caves and other underground spaces, etc.) using visual (direct inspections) and acoustic approaches (bat detectors D-240x, Pettersson Elektronik AB, Uppsala, Sweden, and Batlogger, Elekon AG, Switzerland, were used). Roost surveys were partly based on subsequent inspections of previously identified sites representing baseline data from PAPADATOU et al. (2011).

Acoustic bat activity monitoring in villages. The bat activity surveys were carried out using line walking and/or slow car driving transects in five priority villages of the Municipality of Prespa: Krystallopigi, Lemos, Psarades, Pyli, Vrontero. Bat surveys were usually conducted half an hour after twilight using the automatic ultrasound detector Batlogger M (Elekon AG, Switzerland). Walking and driving transects 
within the villages were roughly the same as the transects of the light pollution survey conducted in the same village (see below). This survey was supplemented by three stationary recordings of bats in 2019 .

Car-based acoustic monitoring of bat activity. Bat car-based surveys started in different villages and covered as many habitats as possible (both urbanised/lighted and rural ones). All acoustic sessions were conducted using the automatic ultrasound detector Batlogger M (Elekon AG, Switzerland) with the

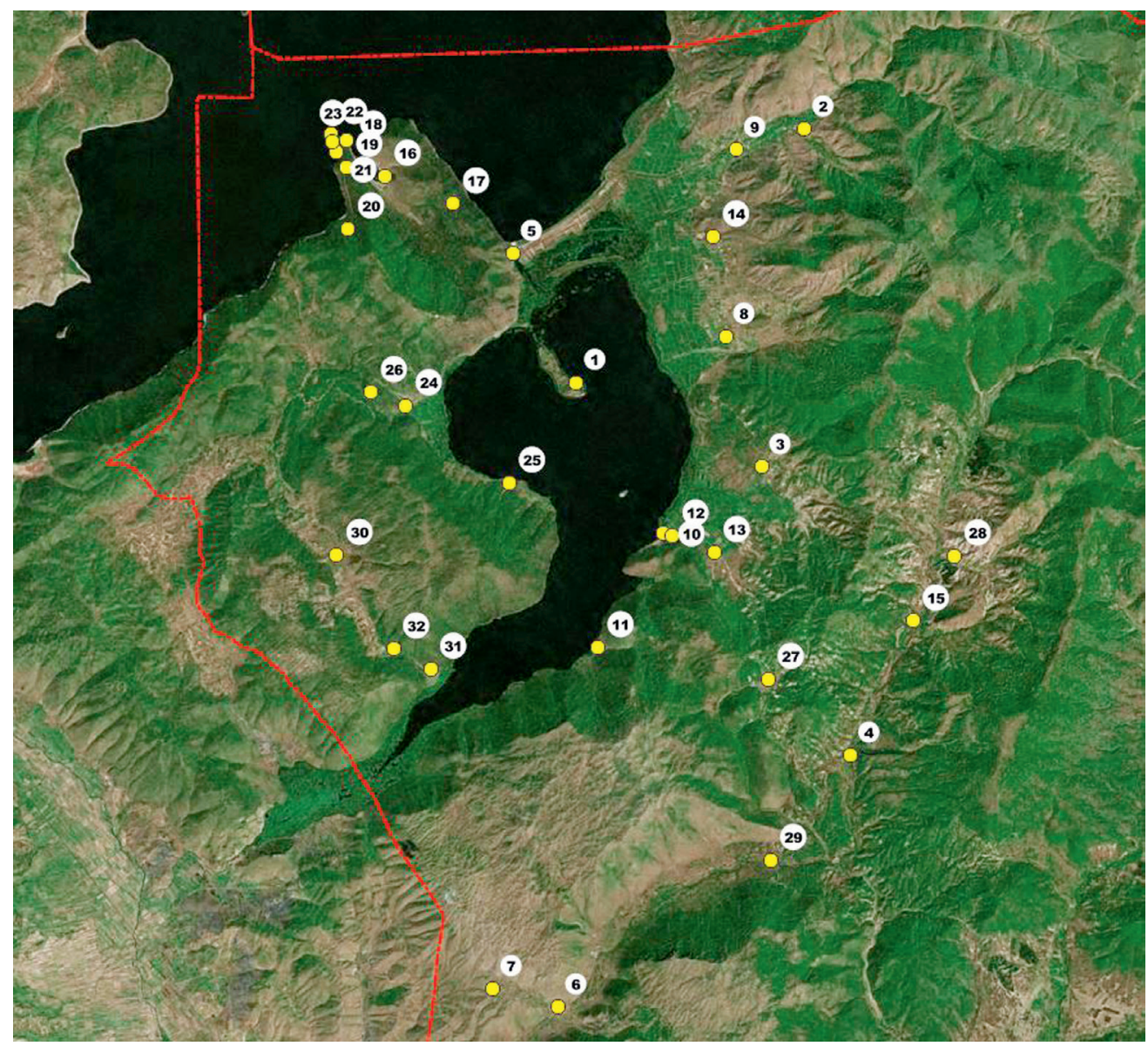

Fig. 1. General map of the study region of the Prespa basin, northern Greece.

Obr. 1. Mapa študovanej oblasti Prespanskej kotliny, severné Grécko.

Sites / Lokality: 1 -Ag. Achillios, Panagia Porphyra; 2 -Ag. Germanos; 3 - Karyes; 4 - Kotas; 5 - Koula; 6 - Krystallopigi; 7 - Moschochóri; 8 - Lefkonas; 9 - Lemos; 10 - Mikrolimni; 11 - Kranies; 12 - Mikrolimni cave; 13 - Oxya; 14 - Plati; 15 - Prasino, Ladopotamos river; 16 - Psarades; 17 - Ag. Georgios; 18 - Archaeological cave; 19 - Cape Roti; 20 - Devas; 21 - Hermitage of Metamorphosis; 22 - Roti cave; 23 - Tcherna cave; 24 - Pyli; 25 - Daseri; 26 - Zachariadis cave; 27 - Sfika; 28 - Trigono; 29 - Vatochori; 30 - Vrontero; 31 - Agkathoto; 32 - Kokkalis cave. 
Table 1. A list of acoustic bat surveys conducted in the Prespa region in the period 2018-2020

Tab. 1. Prehl'ad akustických prieskumov netopierov v Prespanskej kotline v období 2018-2020

\begin{tabular}{|c|c|c|c|}
\hline type / typ & transect / transekt & $\mathrm{km}]$ & date / dátum \\
\hline \multirow{10}{*}{$\begin{array}{l}\text { walk and/or slow } \\
\text { car drive } \\
\text { / chôdza alebo } \\
\text { pomalá jazda }\end{array}$} & Agios Germanos & 2 & 18 September 2018 \\
\hline & Krystallopigi & 6 & 17 September 2018 \\
\hline & & & 30 September 2020 \\
\hline & Lemos & 3 & 1 October 2020 \\
\hline & Psarades & 4 & 15 September 2018 \\
\hline & & & 28 September 2020 \\
\hline & Pyli & 4 & 19 September 2018 \\
\hline & & & 28 September 2020 \\
\hline & Vrontero & 4 & 16 September 2018 \\
\hline & & & 29 September 2020 \\
\hline \multirow{3}{*}{$\begin{array}{l}\text { stationary } \\
\text { / stacionárny }\end{array}$} & Koula & 0 & 8 June 2019 \\
\hline & Prasino, Lapotamos river & 0 & 5 June 2019 \\
\hline & Sfika & 0 & 7 June 2019 \\
\hline \multirow[t]{11}{*}{ car / auto } & Agios Germanos - Krystallopigi & 74 & 17 September 2018 \\
\hline & & & 18 September 2018 \\
\hline & Agios Germanos - Vrontero - Psarades & 36 & 2 October 2020 \\
\hline & Krystallopigi - Agios Germanos & 37 & 30 September 2020 \\
\hline & Krystallopigi - Lemos & 36 & 6 June 2019 \\
\hline & Lemos - Krystallopigi - Agios Germanos & 36 & 1 October 2020 \\
\hline & Psarades - Vrontero - Agios Germanos & 88 & 15 September 2018 \\
\hline & & & 28 September 2020 \\
\hline & Vrontero - Agios Germanos - Mikrolimni & 41 & 4 June 2019 \\
\hline & Vrontero - Psarades - Agios Germanos & 72 & 16 September 2018 \\
\hline & & & 29 September 2020 \\
\hline
\end{tabular}

total / úhrnom

443

24

microphone fixed on the car roof (Hama exhausting tripod was used). The detector automatically recorded bat calls, as well as the geographic position of and the air temperature at the site. The surveys were implemented with the maximum car speed of $40 \mathrm{~km} / \mathrm{h}$ (see CELuch et al. 2016).

All acoustic recordings were analysed for bat species identification and abundance (i.e., numbers of recordings and bat calls) by the respective software (BatExplorer, Elekon AG, Switzerland and BatSound Pro, Pettersson Elektronik AB, Uppsala, Sweden). For the species identification, call parameters described for European bat species and/or from the respective region were applied (PAPADATOU et al. 2008, MidDLETON et al. 2014, BARATAUD 2015, M. Uhrin, unpubl. data). Because of the migratory behaviour in Pipistrellus nathusii, which occurs in the region mostly in the autumn period (see HANÁK et al. 2001 and BENDA et al. 2019 for a review) and due to the overlap of its echolocation characteristics with those of $P$. kuhlii (e.g., OBrist et al. 2004, PAPADATOU et al. 2008), all registered calls with these parameters from September are affiliated to $P$. kuhlii / nathusii.

All bat observations were compiled as standard faunistic records in Results. The literature data are organised in a simplified way only as a list of the sites of occurrence, each supplemented with a particular reference. Original data obtained mostly during the three field trips in 2018, 2019, and 2020 are provided with full faunistic information, where available (e.g., site name and its short description, date of observation, numbers of bat individuals and some more details on habitats, roosts, and survey method used). Taking 
into account limitations of the methods used (acoustic survey and roosts checks only), we were not able to record certain species (e.g. particular species of the genus Myotis) without application of e.g., netting, as was used by the previous researchers (HANÁK et al. 2001, GREMILLET et al. 2010, PAPADATOU et al. 2011). For this reason, further we comment only on the species that we recorded ourselves during the surveys.

Light pollution survey. Light intensity was measured in five prioritized villages of the Municipality of Prespa (Krystallopigi - 17 September 2018, 30 September 2020; Lemos - 18 September 2018, 1 October 2020; Psarades - 15 September 2018, 2 October 2020; Pyli - 19 September 2018, 2 October 2020; Vrontero - 16 September 2018, 29 September 2020). The gauging started after nightfall at ca. 20:30 and was carried out by one person only in a grid of ca. 100 steps using a luxmeter (Multifunctional Environment Measuring Instrument VC-4 in 1, Voltcraft). At each point (which were georeferenced using the Garmin GPS position receiver) of the gauging, the luxmeter was hold in the same position (horizontal and perpendicular to the measuring person body) and it was oriented to the nearest light source. The second person recorded the values gauged and further notes (e.g., lamp type, light colour, cover lamp presence, distances from the nearest light source etc.), and oversaw keeping of distances between the gauging points. In the villages monitored, the gauging team walked through each important street on the basis of a prepared plan. Light intensity directly under selected lamps which represented very strong luminosity sources and various shapes and types of lamps that occured in the monitored villages were also recorded. Basic descriptive statistics were counted using the Past and Graph Pad Prism 5 softwares for data analysis (ver. 4.03; HAMMER et al. 2001). All bat records were georeferenced and geographically visualised and analysed using Quantum GIS (QGIS) software mostly using satellite Bing Maps. The lighting surveys in general followed recommendations from Guidelines for Consideration of Bats in Lighting Projects (VoIGT et al. 2018a), supplemented by several further project results and/or recommendations (PATRIARCA \& DEBERNARDI 2010, Mohar et al. 2014, VerovniK et al. 2015, Zeale et al. 2016, Pauwels et al. 2019). It is important to survey baseline light levels in the areas where the mitigation measures will be implemented to be able to assess the relative change in luminance as a result of the interventions. Thus, the survey was conducted in the above-described way after the change of some light sources (but only lamps on wooden poles were changed in late summer of 2020) in the respective villages.

\section{RESULTS AND DISCUSSION}

In total, mostly during the period of 2018-2020 we obtained at least 486 records of 22 bat forms (20 species) at 323 sites; most of these records $(90.1 \%)$ were made by the acoustic surveys (Table 2). The recorded number of species represented ca. $65 \%$ of all bat diversity currently known in the wider Prespa region (Table 3).

\section{Annotated list of bat records}

\section{Rhinolophus ferrumequinum (Schreber, 1774)}

Original Data. Koula: 15 September 2018 - min. 1 ind. detected \& recorded; Prespa lake shore, 8 June 2019 - several inds. detected \& recorded. Lemos: 4 June 2019 - min. 1 ind. detected \& recorded. Mikrolimni: Mikrolimni cave, 17 September 2018 - 10-30 torpid inds. obs., 19 September 2018 - 3 torpid inds. obs. Oxya: old church at cemetery, 5 June 2019 - 2 inds. obs. Pyli: Zachariadis cave, 15 September 2018 - 1 ind. obs. Psarades: 28 September 2020 - min. 1 ind. detected \& recorded. Psarades: Hermitage of Metamorphosis, cave $\mathrm{N}$ of the site, 18 September 2018 - 1 active ind. obs.; Tcherna cave, 1 October 2020 - several inds. in lethargy obs. Vrontero: Kokkalis cave, 5 June 2019 - 1 active ind. obs.

Published data. Pyli - Zachariadis cave (HanÁK et al. 2001); Prespa region (Gremillet et al. 2010); Agathoto, Agios Germanos, Agios Germanos (barn), Agios Germanos sheepfolds, Analipsi Hermitage, Cape Roti trail, Kokkalis cave, Mikrolimni (biological station), Mikrolimni Cave, Milionas (Seltsa), Mt. 
Table 2. Number of records and sites of bats recorded in the Prespa region in the period 2018-2020 Tab. 2. Počet záznamov a lokalít netopierov v Prespanskej kotline v období 2018-2020; roosts = úkryty

\begin{tabular}{lrrrrrr}
\hline species / druh & \multicolumn{2}{c}{ no. of records / počet záznamov } & \multicolumn{2}{c}{ no. of sites / počet lokalít } \\
& acoust. / akust. & roosts & $\Sigma$ & $\%$ & $\Sigma$ & $\%$ \\
\hline Rhinolophus ferrumequinum & 4 & 7 & 11 & 2.3 & 10 & 3.1 \\
Rhinolophus hipposideros & 1 & 19 & 20 & 4.1 & 12 & 3.7 \\
Rhinolophus euryale & 2 & 1 & 3 & 0.6 & 3 & 0.9 \\
Myotis myotis & & 3 & 3 & 0.6 & 2 & 0.6 \\
Myotis emarginatus & 2 & & 2 & 0.4 & 2 & 0.6 \\
Myotis daubentonii & 7 & 1 & 8 & 1.6 & 8 & 2.5 \\
Myotis capaccinii & 1 & 4 & 5 & 1.0 & 4 & 1.2 \\
Myotis sp. & 32 & & 32 & 6.6 & 23 & 7.1 \\
Eptesicus serotinus & 18 & & 18 & 3.7 & 15 & 4.6 \\
Eptesicus nilssonii & 1 & & 1 & 0.2 & 1 & 0.3 \\
Hypsugo savii & 21 & & 21 & 4.3 & 18 & 5.6 \\
Pipistrellus pipistrellus & 96 & & 96 & 19.8 & 42 & 13.0 \\
Pipistrellus pygmaeus & 29 & & 29 & 6.0 & 24 & 7.4 \\
Pipistrellus kuhlii & 28 & & 28 & 5.8 & 27 & 8.4 \\
Pipistrellus kuhlii / P. nathusii & 99 & & 99 & 20.4 & 50 & 15.5 \\
Nyctalus noctula & 52 & & 52 & 10.7 & 35 & 10.8 \\
Nyctalus lasiopterus & 9 & & 9 & 1.9 & 9 & 2.8 \\
Nyctalus leisleri & 17 & & 17 & 3.5 & 14 & 4.3 \\
Barbastella barbastellus & 1 & & 1 & 0.2 & 1 & 0.3 \\
Plecotus austriacus & & 3 & 3 & 0.6 & 2 & 0.6 \\
Plecotus sp. & 2 & & 2 & 0.4 & 2 & 0.6 \\
Miniopterus schreibersii & 6 & 2 & 8 & 1.6 & 7 & 2.2 \\
Tadarida teniotis & 16 & 2 & 18 & 3.7 & 12 & 3.7 \\
\hline E & 439 & 43 & 486 & 100.0 & 323 & 100.0 \\
\hline & & & & & &
\end{tabular}

Devas 1, Oxya, Psarades/Agios Nikolaos, Psarades Flea Cave, Tcherna Cave, Zachariadis Cave (PAPAdAtou et al. 2011); Moutsara (PAPADATOU et al. 2013).

We registered the greater horseshoe bat (Rhinolophus ferrumequinum) at ten sites (Fig. 2A), the species with 11 records of mostly solitary individuals represents only $3.1 \%$ of all bat records. Most of our findings come from observations in caves (Hermitage of Metamorphosis, Kokkalis, Mikrolimni, Tcherna, Zachariadis), while acoustic records and man-made roost occurrences were scarce. This pattern is similar to the previous reports (HANÁK et al. 2001, GREMILLET et al. 2010, PAPADATOU et al. 2011, 2013), but the presence of a rather large breeding colony reported previously from the Tcherna cave was not currently confirmed.

\section{Rhinolophus hipposideros (Borkhausen, 1797)}

Original Data. Agios Achillios Island: Panagia Porphyra church, 15 September 2018 - 1 active ind. obs.; 4 June 2019 - a colony of 10 inds. obs.; 29 September 2020 - a colony of 7 inds. obs. Agios Germanos: old abandoned village house, 2 October $2020-4$ torpid inds. obs. Mikrolimni: Mikrolimni cave, 19 September 2018 - 3 torpid inds. obs. Oxya: old church at cemetery, 16 September 2018 - a colony of ca. 20 inds. obs.; 5 June 2019 - a colony of 33 inds. obs.; 30 September 2020 - a colony of 11 inds. 
obs. Pyli: Daseri, small church, 15 September 2018 - 1 active ind. obs. Pyli: $300 \mathrm{~m} \mathrm{~W}$ of the village, 2 October 2020 - min. 1 detected \& recorded; Zachariadis cave, 15 September $2018-1$ ind. obs., 30 September $2020-1$ torpid ind. obs. Psarades: Archaeological cave, 20 September $2018-2$ torpid inds. obs.; Tcherna cave, 1 October 2020 - several inds. in lethargy obs. Trigono: church, 17 September $2018-6$ torpid and 1 active inds. obs. Vrontero: Agkathoto church, 16 September 2018 - a colony of 50-60 inds. obs.; 4 June 2019 - a colony of 120 inds. obs.; 29 September 2020 - a colony of 115 inds. (mostly in lethargy) obs.; Kokkalis cave, 16 September 2018 - 1 active and 1 torpid inds. obs.; 5 June 2019 - 1 active ind. obs.

Published data. Pyli - Zachariadis cave (HanÁK et al. 2001); Prespa region (Gremillet et al. 2010); Agathoto, Agios Achilleos, Agios Germanos, Agios Germanos (barn), Agios Germanos (mill), Agios Germanos sheepfolds, Analipsi Hermitage, Gaidouritsa (Mt. Varmous), Giaintsa, Karyes, Kokkalis Cave, Laimos, Metamorphosi Hermitage, Metamorphosi Hermitage (rocky shore), Mikrolimni (biological station), Mikrolimni Cave, Mikros Kampos, Milionas, Oxya, Panagia Eleousa Hermitage, Panagia Porphyra Ruins, Psarades, Psarades/Agios Nikolaos, Seltsa, Tcherna Cave (Papadatou et al. 2011); Moutsara (PaPAdatou et al. 2013).

Among three horseshoe bat species that we recorded during our surveys, the lesser horseshoe (Rhinolophus hipposideros) was the most frequent (altogether 20 records in 12 sites; dominance $4.1 \%$; Fig. 2B). The majority of records are represented by observations in roosts ( 5 old churches, 1 abandoned old building, 4 caves), only once the species was documented acoustically at a car-based transect. The whole breeding population of the species in the Greek part of the Prespa region was estimated to be ca. 700 individuals in total (PAPADATOU et al. 2011), which is in line with our findings; we recorded approximately 400 individuals of $R$. hipposideros in roosts altogether (1-120 inds. per roost). The most numerous breeding colony of this species roosted in the abandoned church of Agkathoto on the lake shore south of the Vrontero village.

\section{Rhinolophus euryale Blasius, 1853}

ORIGINAL DATA. Koula: Prespa lake shore, 8 June 2019 - several inds. detected \& recorded. Krystallopigi: 17 September 2018 - min. 1 ind. detected \& recorded. Mikrolimni: Mikrolimni cave, 17 and 19 September 2018 - a colony of ca. $200-400$ active inds. obs.

Published data. Pyli - Zachariadis cave (HanÁk et al. 2001); Prespa region (Gremillet et al. 2010); Kokkalis Cave, Mt. Devas 1, Tcherna Cave, Zachariadis Cave (Papadatou et al. 2011).

The Mediterranean horseshoe bat (Rhinolophus euryale) is the rarest species of the genus Rhinolophus in the region, we registered four records only (2 acoustic and 1 roost record in 3 sites; Fig. 2C). Nevertheless, our observations confirmed continuing breeding of the species in the Mikrolimni cave, where a colony of up to 400 individuals was observed in September 2018.

\section{Myotis myotis (Borkhausen, 1797)}

Original Data. Psarades: Hermitage of Metamorphosis, cliffs, 18 September 2018 - 2 inds. obs. in fissures; 8 June 2019 - 1 ind. obs. in the same fissure. Vrontero: Kokkalis cave, 29 September $2020-1$ ind. obs. Published data. Prespa region (Gremillet et al. 2010); Kokkalis Cave, Pyxos, Zachariadis Cave (PapaDATOU et al. 2011).

We observed solitary individuals of the greater mouse-eared bat (Myotis myotis) at two sites only, inside a cave roost and in fissures on cliffs of the Prespa lake shore (Fig. 2C). Regarding the scarcity of records (which applies also tor the whole territory of Greece; see HANÁK et al. 
Table 3. A list of bats recorded in the Prespa region and surroundings

Tab. 3. Zoznam netopierov zaznamenaných v širšom okolí Prespanskej kotliny survey type / typ výskumu: ac - acoustic / akustický, rc - roost checks / kontroly úkrytov; sources / zdroje: H01 = HANÁK et al. 2001, G10 = Gremillet et al. 2010, P11 = PAPADATOU et al. 2011, M14 = MiceVsKi et al. 2014, P15 = PresetniK 2015, B19= Benda et al. 2019

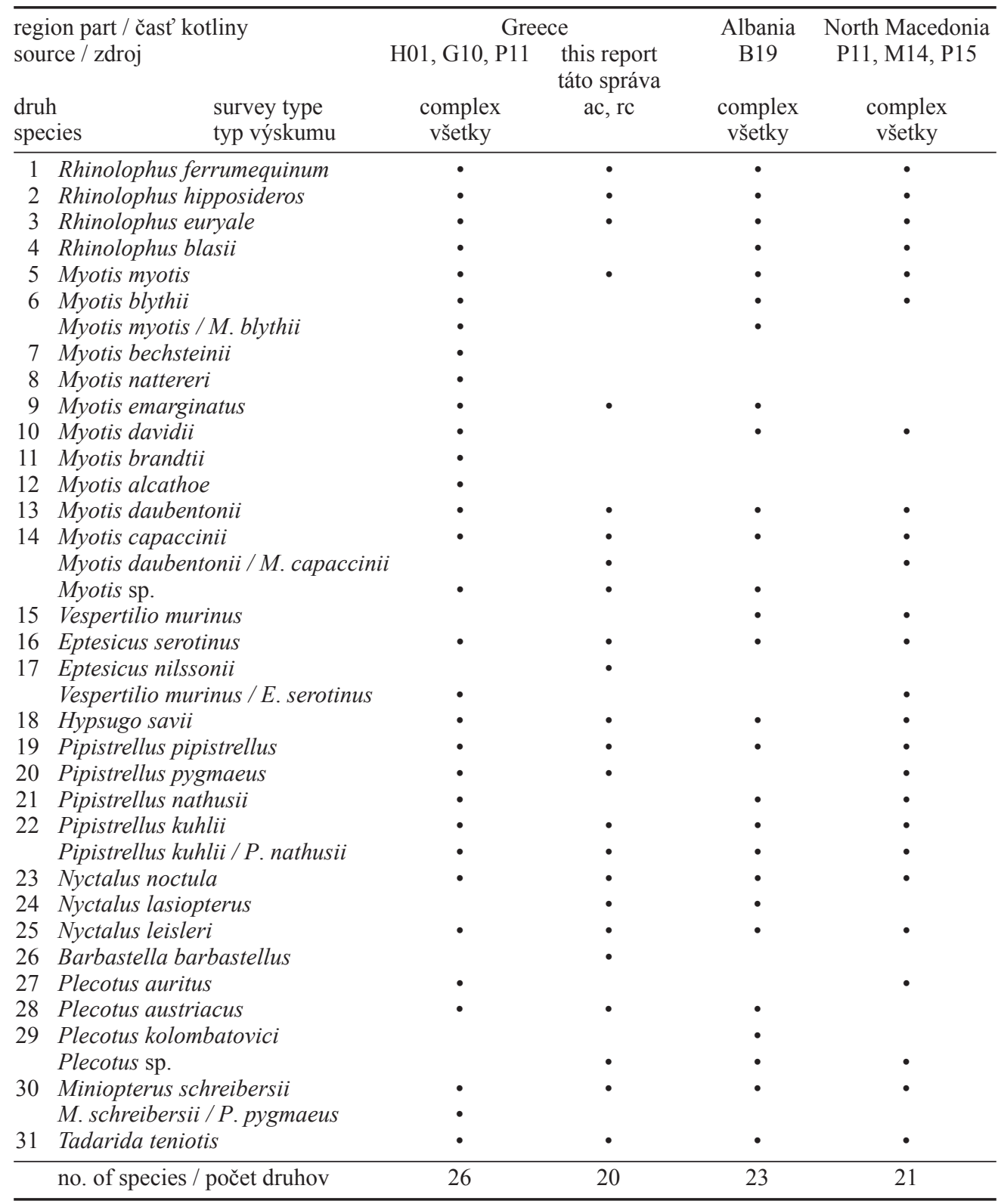


2001), the regional species status is not fully discovered. To the date, no breeding colony has been recorded from this region (PAPADATOU et al. 2011).

\section{Myotis emarginatus (Geoffroy, 1806)}

Original Data. Krystallopigi: 17 September 2018 - min. 1 ind. detected \& recorded. Psarades: 28 September 2020 - min. 1 ind. detected \& recorded.

Published data. Prespa region (Gremillet et al. 2010); Cape Roti Cave, Psarades/Agios Nikolaos, Tcherna Cave, Zachariadis Cave (PAPAdatou et al. 2011).

We recorded echolocation call sequences which could be attributed to Geoffroy's bat (Myotis emarginatus) at two sites only (Fig. 2D), the distributional status of this bat in the region is not clear. Nevertheless, the species seems to form maternity colony there (PAPADATOU et al. 2011). A similar situation concerning the distribution of the Geoffroy's bat is known from the Albanian part of the region (BENDA et al. 2019).

\section{Myotis daubentonii (Kuhl, 1817)}

Original DATA. Koula: 29 September 2020 - min. 1 ind. of Myotis cf. daubentonii detected \& recorded; $1.8 \mathrm{~km} \mathrm{~N}$ of the site, 29 September 2020 - min. 1 ind. of Myotis cf. daubentonii detected \& recorded; Prespa lake shore, 8 June 2019 - several inds. detected \& recorded. Psarades: 28 September 2020 - min. 1 ind. of Myotis cf. daubentonii detected \& recorded; lake port, 15 September 2018 - several inds. of Myotis cf. daubentonii detected \& recorded; Hermitage of Metamorphosis, cave S of the site, 30 September 2020 - 4 inds. obs. Pyli: 29 September 2020 - min. 1 ind. of Myotis cf. daubentonii detected \& recorded; $5.5 \mathrm{~km}$ NE of the village, 29 September 2020 - min. 1 ind. of Myotis cf. daubentonii detected \& recorded. Published data. Prespa lake (von Helversen \& Weid 1990); Prespa region (Gremillet et al. 2010); Agios Achilleos, Cape Roti Cave, Cape Roti (western shore), Giaintsa, Metamorphosi Hermitage (rocky shore), Mikrolimni (rocky cliffs), Psarades/Agios Nikolaos, Tcherna Cave (PAPADATOU et al. 2011).

The Daubenton's bat (Myotis daubentonii) seems to be common species in the area, despite difficulties in species determination of echolocation sequences due to their similarities with those of other species (Myotis capaccinii in this region). Our surveys confirmed presence of this species mostly acoustically (in combination with visual observation of foraging bats above water surfaces) at least on three sites (Koula, Psarades [lake port], Pyli). These records are supplemented by a finding of a small cluster roosting inside a rocky crevice in a cave near the Hermitage of Metamorphosis (Fig. 2E).

\section{Myotis capaccinii (Bonaparte, 1837)}

Original Data. Koula: Prespa lake shore, 8 June 2019 - several inds. detected \& recorded. Psarades: Archaeological cave, 20 September $2018-1$ active ind. obs. Psarades: Hermitage of Metamorphosis,

Fig. 2. Bat distribution in the Greek part of the Prespa basin based on the original data of this report (literature data are not included). Distribution of the particular species (asterisks) is shown against all records of all species (yellow circles).

Obr. 2. Rozšírenie netopierov v gréckej časti Prespanskej kotliny na základe údajov tejto správy (literárne údaje nie sú do máp zahrnuté). Rozšírenie jednotlivých druhov (hviezdičky) je zobrazené na pozadí všetkých nálezov všetkých druhov (žlté krúžky). 

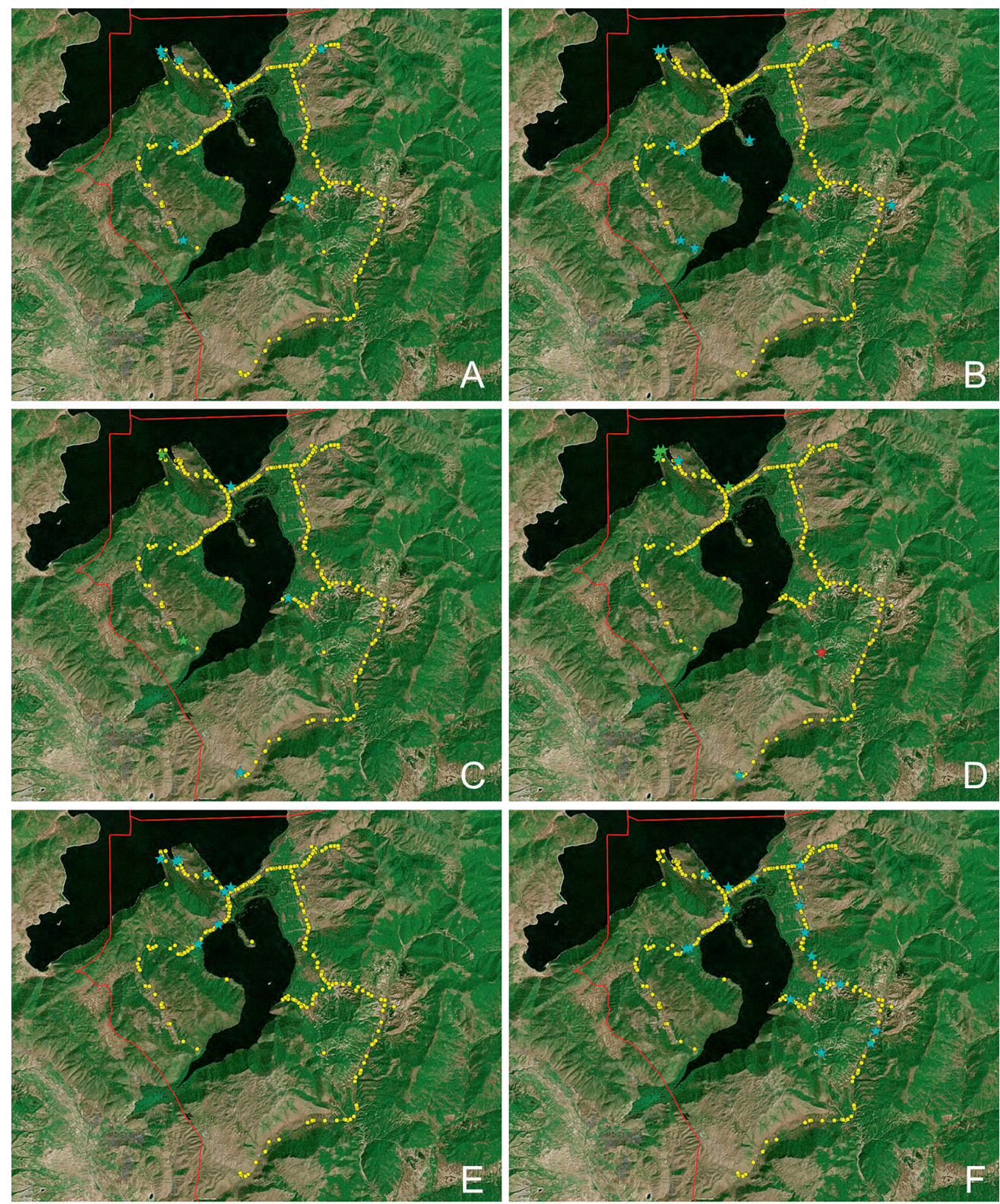

A-Rhinolophus ferrumequinum, B - Rhinolophus hipposideros, C-Rhinolophus euryale [blue / modro], Myotis myotis [green / zeleno], D - Myotis emarginatus [blue / modro], Myotis capaccinii [green / zeleno], Eptesicus nilssonii [red / červeno], E-Myotis daubentonii, F - Eptesicus serotinus. 
cave S of the site, 18 September 2018 - 1 active ind. obs.; 8 June 2019 - a colony of min. 30 inds. inds. obs. Psarades: Tcherna cave, 1 October 2020 - ca. 20 active inds. obs. (in two clusters).

Published data. Prespa region (Gremillet et al. 2010). Cape Roti Cave, Giaintsa, Kokkalis Cave, Psarades/ Agios Nikolaos, Tcherna Cave (PAPADATou et al. 2011).

The regional status of the long-fingered bat (Myotis capacinii) seems to be similar to the previous species, they usually live there in sympatry and syntopy. Individuals or even aggregations (including nursery colonies) of $M$. capaccinii were found in several caves all over the region (Gremillet et al. 2010, Papadatou et al. 2011). During our surveys, we recorded this species at five sites, most of them are roost observations (Fig. 2D).

\section{Myotis sp.}

Original Data. Koula: up to $2 \mathrm{~km} \mathrm{~S}$ of the site, 15 September 2018, 28 and 29 September 2020, 2 October 2020 - several inds. detected \& recorded; $1.5 \mathrm{~km}$ E of the site, 15 September 2018 - min. 1 ind. detected \& recorded; Prespa lake shore, 8 June 2019 - several inds. detected \& recorded. Krystallopigi: 17 September 2018 - several inds. detected \& recorded. Lefkonas: $0.8-1.2 \mathrm{~km} \mathrm{~S}$ of the village, 18 September 2018, 6 June 2019, 1 October 2020 - min. 1 ind. detected \& recorded. Lemos: $0.5 \mathrm{~km} \mathrm{SW}$ of the village, 16 September 2018 - min. 1 ind. detected \& recorded. Milionas: $1 \mathrm{~km} \mathrm{~W}$ of the site, 15 September 2018 - min. 1 ind. detected \& recorded. Oxya: $0.5 \mathrm{~km} \mathrm{~W}$ of the village, 18 September $2018-\mathrm{min} .1$ ind. detected \& recorded; $1.2 \mathrm{~km} \mathrm{NE}$ of the village, 4 June $2019-$ min. 1 ind. detected \& recorded. Plati: $0.5 \mathrm{~km} \mathrm{~W}$ of the village, 1 October $2020-\min .1$ ind. detected \& recorded. Prasino: $0.8 \mathrm{~km} \mathrm{~S}$ of the village, 17 September 2018 - min. 1 ind. detected \& recorded; Ladopotamos river, 5 June 2019 - several inds. detected \& recorded. Psarades: 15 September 2018, 28 September 2020 - several inds. detected $\&$ recorded; Agios Georgios, 29 September 2020 - min. 1 ind. detected \& recorded; Devas, 2 October 2020 - min. 1 ind. detected \& recorded. Pyli: 19 September 2018 - min. 1 ind. detected \& recorded; $1 \mathrm{~km}$ NE of village, 15 September 2018 - min. 1 ind. detected \& recorded; $2.5-3.5 \mathrm{~km}$ E of the village, 28 and 29 September 2020 - several inds. detected \& recorded; $0.5 \mathrm{~km} \mathrm{~W}$ of the village, 28 September 2020 - several inds. detected \& recorded; $2.5 \mathrm{~km} \mathrm{~W}$ of the village, 2 October 2020 - several inds. detected \& recorded. Sfika: 7 June 2019 - several inds. detected \& recorded. Vrontero: 16 September 2018, 29 September 2020, 2 October 2020 - min. 1 ind. detected \& recorded; $1.4 \mathrm{~km} \mathrm{~S}$ of the village, 4 June 2019 - min. 1 ind. detected \& recorded.

Altogether 32 records of representatives of the genus Myotis from 23 sites were registered acoustically during the surveys in the region. It was not possible to attribute these recordings to particular species, thus, this set of records may cover several different species (e.g., Myotis myotis, M. blythii, M. bechsteinii, M. nattereri, M. davidii, M. brandtii, M. alcathoe).

\section{Eptesicus serotinus (Schreber, 1774)}

Original Data. Karyes: $1.5 \mathrm{~km}$ E of the village, 18 September 2018 - min. 1 ind. detected \& recorded. Karyes, $500 \mathrm{~m} \mathrm{~S}$ of the village, 4 June 2019 - min. 2 inds. detected \& recorded. Karyes: $1.5 \mathrm{~km} \mathrm{~N}$ of the village, 6 June 2019 - min. 2 ind. detected \& recorded. Koula: $1.2 \mathrm{~km} \mathrm{~S}$ of the site, 29 September 2020 - min. 1 ind. detected \& recorded; Prespa lake shore, 8 June 2019 - several inds. detected \& recorded.

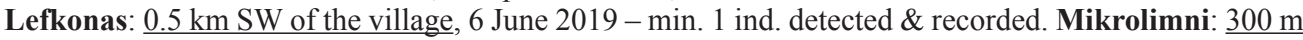
E of the village, 18 September 2018 - min. 1 ind. detected \& recorded, 4 June 2019 - min. 1 ind. detected \& recorded. Milionas: $400 \mathrm{~m}$ NW of the village, 18 September 2018 - min. 1 ind. detected \& recorded. Plati: $1.2 \mathrm{~km} \mathrm{~S}$ of the village, 6 June $2019-\min .1$ ind. detected \& recorded. Prasino: $1 \mathrm{~km} \mathrm{~S}$ of the village, 6 June 2019 - min. 2 inds. detected \& recorded; Ladopotamos river, 5 June 2019 - several inds. detected \& recorded. Psarades: Agios Georgios, 29 September 2020 - min. 1 ind. detected \& recorded. 
Pyli: 19 September 2018 - several inds. detected \& recorded, 28 September 2020 - min. 1 ind. detected \& recorded, 2 October 2020 - min. 1 ind. detected \& recorded. Sfika: 7 June 2019 - min. 1 ind. detected $\&$ recorded.

Published data. Prespa region (Gremillet et al. 2010); Agios Germanos River (estuary), Agios Germanos River (ford) (PAPADATOU et al. 2011).

Despite the scarcity of published records (Gremillet et al. 2010, Papadatou et al. 2011), the serotine (Eptesicus serotinus) seems to be rather common in the region. We made 18 acoustic records at 15 sites (Fig. 2F), but these data do not answer the question whether the species breeds in the region. However, the reproduction is very likely, since we recorded it acoustically at several sites of the region also in summer, in the period of existence of maternity colonies.

\section{Eptesicus nilssonii (von Keyserling et Blasius, 1839)}

Original Data. Sfika: 7 June 2019 - min. 1 ind. detected \& recorded.

The northern bat (Eptesicus nilssonii) has been included neither in the list of bats of the Prespa region nor in the list of the bat fauna of Greece (HANÁK et al. 2001). Nevertheless, considering its distribution pattern including some records from the northern and central parts of the Balkans (e.g., HanÁK \& HorÁČEK 1986, PAvlinić \& Tvrtković 2003, Uhrin et al. 2014), this species was considered to be candidate for possible addition to the list of Greek bat fauna. Recently, new records of $E$. nilssonii represented by echolocation calls have been reported also from northern Albania (BENDA et al. 2019). In the Prespa region, we recorded two echolocation call sequences (altogether 22 particular calls) at the abandoned village of Sfika (Fig. 2D), which can be attributed to this species. The site is situated at the altitude of ca. 1,220 m a. s. 1 . and is similar in its general habitat to other Balkan sites, where E. nilssonii was recorded (for review see BENDA et al. 2019). Anyway, the occurrence of this bat species in the region and in Greece as well requires confirmation by an evidence of a specimen.

\section{Hypsugo savii (Bonaparte, 1837)}

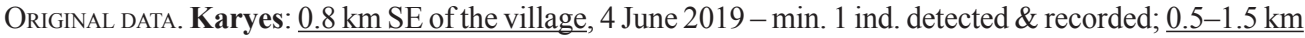
$\mathrm{N}$ of the village, 6 June $2019-\min .1$ ind. detected \& recorded. Koula: 2 October $2020-$ min. 1 ind. detected \& recorded; $0.5-1.2 \mathrm{~km} \mathrm{~S}$ of the site, 15 September 2018 - min. 1 ind. detected \& recorded; 4 June 2019 - min. 1 ind. detected \& recorded; $1.8-3.6 \mathrm{~km}$ E of the site, 4 June 2019 - min. 1 ind. detected $\&$ recorded, 28 September 2020 - min. 1 ind. detected \& recorded, 29 September 2020 - several inds. detected \& recorded; Prespa lake shore, 8 June 2019 - several inds. detected \& recorded. Krystallopigi: 17 September 2018 - min. 1 ind. detected \& recorded. Lefkonas: $1.5 \mathrm{~km} \mathrm{~S}$ of the village, 1 October 2020 - min. 1 ind. detected \& recorded. Lemos: 1 October 2020 - min. 1 ind. detected \& recorded; $1.2 \mathrm{~km} \mathrm{SW}$ of the village, 16 September 2018 - min. 1 ind. detected \& recorded. Plati: $0.5 \mathrm{~km} \mathrm{NW}$ of the village, 1 October 2020 - min. 1 ind. detected \& recorded. Psarades: Agios Georgios, 29 September 2020 - min. 1 ind. detected \& recorded; lake port, 15 September 2018 - min. 1 ind. detected \& recorded. Pyli: 28 September 2020 - min. 1 ind. detected \& recorded. Trigono: $1 \mathrm{~km}$ and $2.5 \mathrm{~km} \mathrm{~W}$ of the village, 6 June 2019 - min. 2 inds. detected \& recorded. Vrontero: $1.7 \mathrm{~km} \mathrm{~N}$ of the village, 28 September 2020 - min. 1 ind. detected \& recorded.

Published data. Bella Voda (Galand et al. 2010, Vrahnakis et al. 2010); Prespa region (Gremillet et al. 2010); Agios Achilleos, Agios Germanos, Agios Germanos River, Agios Germanos River (estuary), Agios Germanos River (ford), Bella Voda (Mt. Varnous), Cape Roti (western shore), Gaidouritsa (Mt. Varnous), Giaintsa, Kokkalis Cave, Krina, Mazi - Kirko (Mt. Varnous), Metamorphosi Hermitage (rocky shore), 
Mikrolimni (biological station), Mt. Devas 1, Mt. Devas 2, Sfika (Mt. Triklario), Sfika ruins, Tcherna Cave (Papadatou et al. 2011); Bella Voda, Mazi-Kirko, Sfika (Papadatou et al. 2013).

The Savi's pipistrelle (Hypsugo savii) appears to be a common and widespread bat in the region, from where it is known as a breeding species (PAPADATOU et al. 2011). In the Prespa region, we recorded it only acoustically at 18 sites altogether (Fig. $2 \mathrm{G}$ ), though less frequently than other pipistrelle bats (0.6-5.3\% of all echolocation recordings; for details see Tables 4 and 5).

\section{Pipistrellus pipistrellus (Schreber, 1774)}

Original Data. Agios Germanos: 17 September 2018, 4 June 2019, 28 September 2020 - several inds. detected \& recorded. Karyes: 18 September 2018 - min. 1 ind. detected \& recorded; $0.5-3 \mathrm{~km}$ E of the village, 17 September 2018, 1 October 2020 - min. 1 ind. detected \& recorded; $1 \mathrm{~km}$ SE of the village, 18 September 2018 - min. 1 ind. detected \& recorded; $0.5-2 \mathrm{~km} \mathrm{NE}$ of the village, 1 October $2020-$ several inds. detected \& recorded. Kotas: $1.8 \mathrm{~km} \mathrm{~S}$ of the village, 17 September 2018, 30 September 2020 - min. 1 ind. detected \& recorded; $0.5-1 \mathrm{~km} \mathrm{NE}$ of the village, 17 and 18 September $2018-$ min. 1 ind. detected \& recorded. Koula: 15 September 2018, 28 September 2020 - several inds. detected $\&$ recorded; up to $2 \mathrm{~km} \mathrm{~S}$ of the site, 15 and 16 September 2018, 4 June 2019, 28 and 29 September 2020, 2 October 2020 - several inds. detected \& recorded; up to Agios Georgios, 29 September 2020 - many inds. detected \& recorded; up to $3.5 \mathrm{~km}$ E of the site, 15 and 16 September 2018, 4 June 2019, 28 September 2020 - several inds. detected \& recorded, 29 September 2020 - many inds. detected \& recorded; Prespa lake shore, 8 June 2019 - several inds. detected \& recorded. Krystallopigi: 18 September 2018, 1 October 2020 - min. 1 ind. detected \& recorded, 30 September 2020 - many inds. detected \& recorded; 2-3.5 km NE of the village, 18 September 2018, 30 September 2020, 1 October 2020 - min. 1 ind. detected \& recorded. Lefkonas: 17 September 2018 - min. 1 ind. detected \& recorded; $1.2 \mathrm{~km} \mathrm{~N}$ of the village, 18 September 2018 - several inds. detected \& recorded. Lemos: 17 and 18 September 2018, 30 September 2020, 1 October 2020 - several inds. detected \& recorded; $0.5-1 \mathrm{~km} \mathrm{SW}$ of the village, 16 and 18 September 2018, 28 and 29 September 2020 - min. 1 ind. detected \& recorded. Mikrolimni: 18 September 2018, 4 June 2019 - min. 1 ind. detected \& recorded. Milionas: $1.2 \mathrm{~km}$ E of the village, 29 September 2020 - min. 1 ind. detected \& recorded. Oxya: up to $2 \mathrm{~km}$ E of the village, 18 September 2018, 4 June 2019 - several inds. detected \& recorded; $0.5-1 \mathrm{~km} \mathrm{~W}$ of the village, 18 September 2018 min. 1 ind. detected \& recorded. Plati: $0.5-1 \mathrm{~km} \mathrm{NW}$ of the village, 4 June 2019,1 October 2020 - min. 1 ind. detected \& recorded; $1.2 \mathrm{~km} \mathrm{~S}$ of the village, 1 October $2020-$ min. 1 ind. detected \& recorded. Prasino: $1 \mathrm{~km} \mathrm{SW}$ of the village, 17 September 2018 - several inds. detected \& recorded; Ladopotamos $\underline{\text { river, }} 5$ June 2019 - min. 1 ind. detected \& recorded. Psarades: 30 June 2015, 15 and 19 September 2018, 28 and 29 September 2020, 2 October 2020 - several inds. detected \& recorded; $\underline{0.5-1.5 \mathrm{~km} \text { SE of the }}$ village, 15 and 16 September 2018, 29 September 2020, 2 October $2020-$ min. 1 ind detected \& recorded; $300 \mathrm{~m} \mathrm{~W}$ of the village, 2 October 2020 - min. 1 ind. detected \& recorded; Agios Georgios, 15 and 16 September 2018, 2 October 2020 - several inds. detected \& recorded. Pyli: 15 September 2018, 4 June 2019, 28 and 29 September 2020, 2 October 2020 - several inds. detected \& recorded; $\underline{0.5-3 \mathrm{~km} \text { E of the }}$ village, 15 and 16 September 2018, 28 and 29 September 2020, 2 October 2020 - several inds. detected \& recorded; $0.5-2.5 \mathrm{~km} \mathrm{~W}$ of the village, 15 and 16 September 2018, 4 June 2019. 29 September 2020 - several inds. detected \& recorded. Sfika, 7 June 2019 - several inds. detected \& recorded. Trigono: $0.5 \mathrm{~W}$ of the village, 6 June 2019 - min. 1 ind. detected \& recorded. Vatochori: $0.8 \mathrm{~km} \mathrm{~W}$ of the village, 17 September 2018 - min. 1 ind. detected \& recorded; $0.5-1.6 \mathrm{~km}$ E of the village, 18 September 2018, 1 October 2020 - min. 1 ind. detected \& recorded. Vrontero: 15 September 2018 - min. 1 ind. detected $\&$ recorded, 16 September 2018, 29 September 2020 - several inds. detected \& recorded; $0.5-3.5 \mathrm{~km} \mathrm{~N}$ of the village, 15 and 16 September 2018, 28 and 29 September 2020 - several inds. detected \& recorded; $1.5 \mathrm{~km} \mathrm{~S}$ of the village, 4 June $2019-$ min. 1 ind. detected \& recorded.

Published data. Pyli (HAnÁK et al. 2001); Bella Voda (Galand et al. 2010, VRahnakis et al. 2010); Prespa region (Gremillet et al. 2010); Agios Achilleos, Agios Germanos River, Agios Germanos River (ford), 

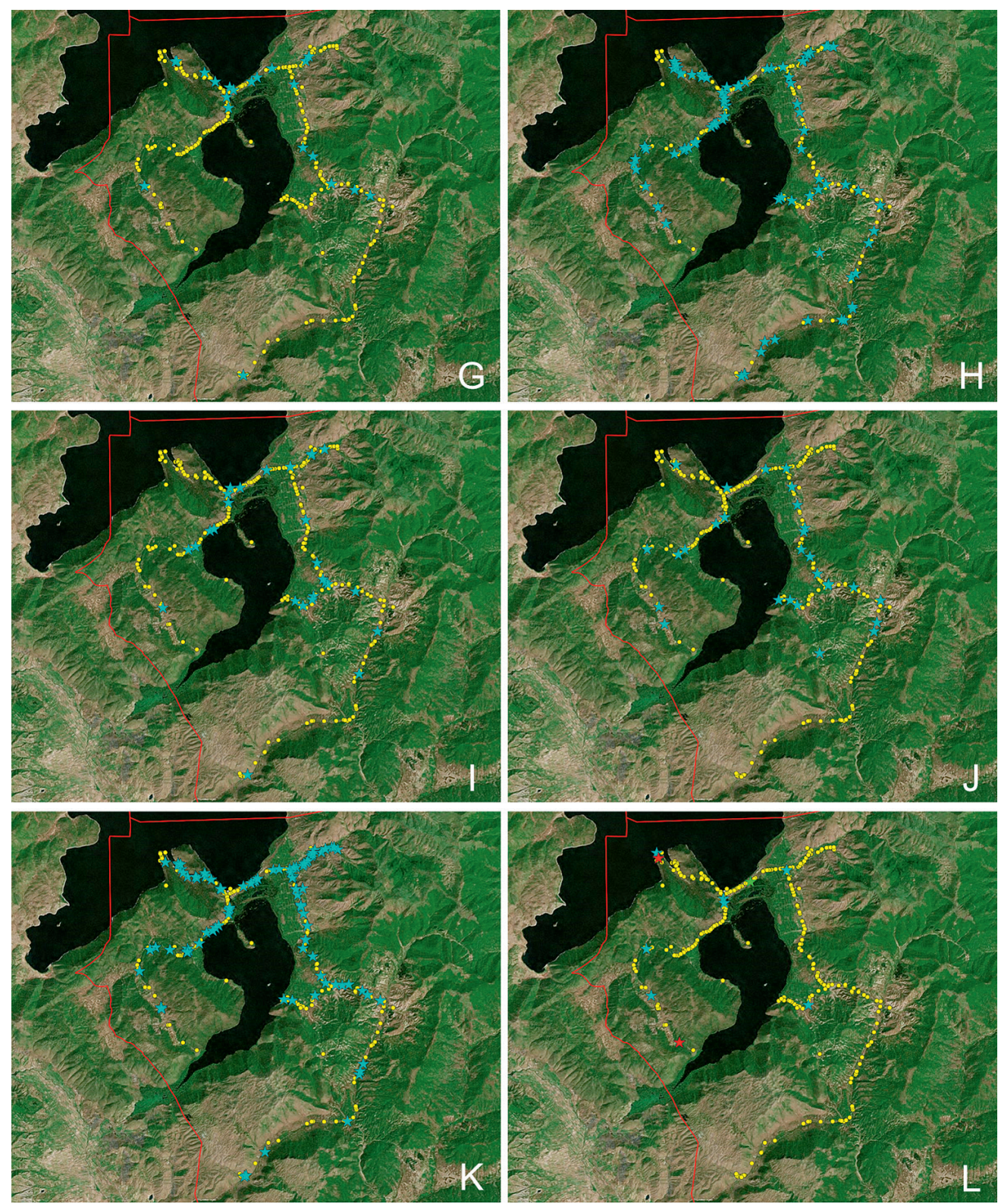

Fig. 2. (continued)

Obr. 2. (pokračovanie)

G - Hypsugo savii, H - Pipistrellus pipistrellus, I - Pipistrellus pygmaeus, J - Pipistrellus kuhlii, K Pipistrellus kuhlii / nathusii, L - Barbastella barbastellus [green / zeleno], Plecotus austriacus [red / červeno], Miniopterus schreibersii [blue / modro]. 


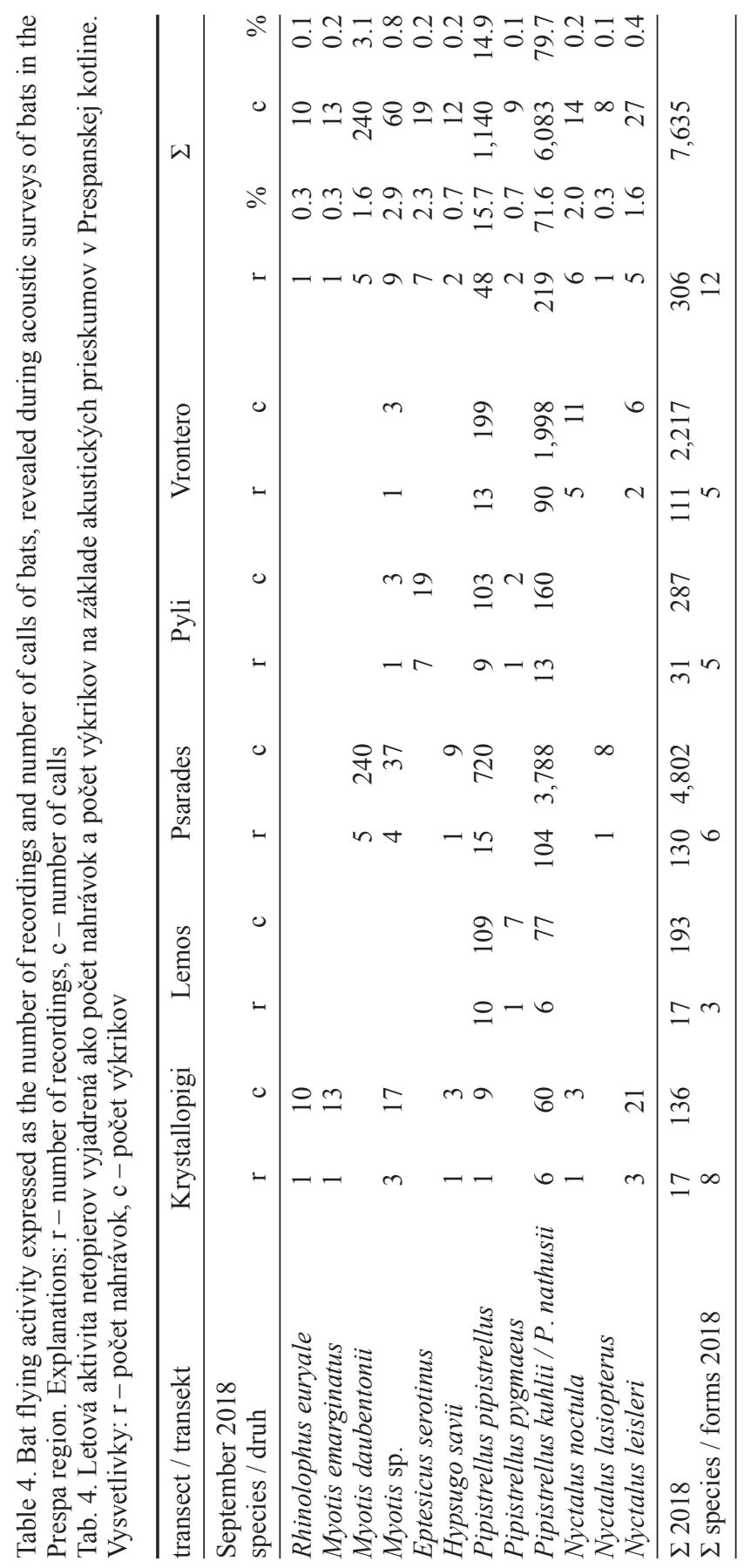




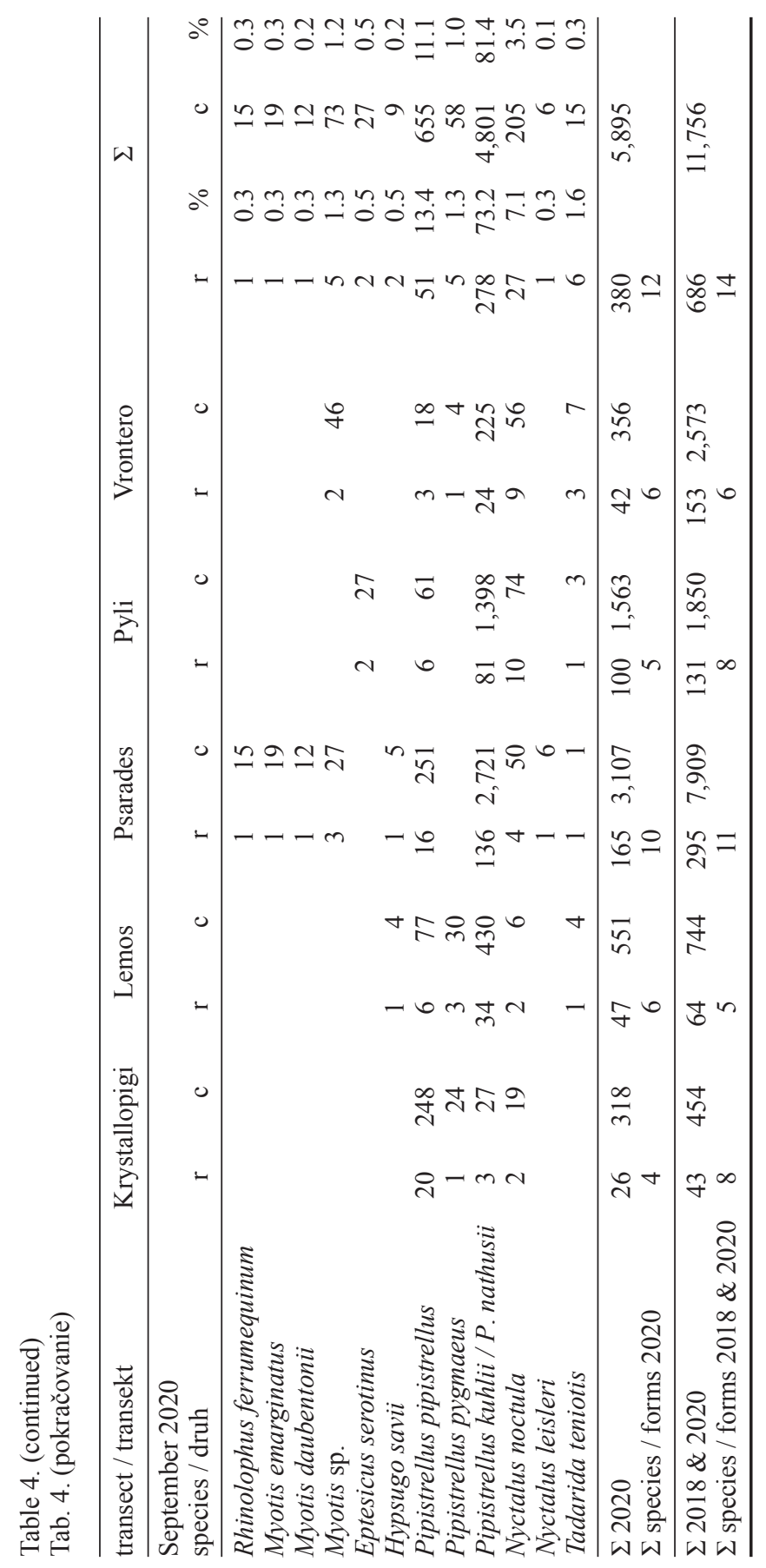


Bella Voda (Mt. Varnous), Bouskani, Cape Roti trail, Gaidouritsa (Mt. Varnous), Kokkalis Cave, Koula, Krina, Mazi-Kirko (Mt. Varnous), Mt. Devas 2, Platy, Pyxos, Sfika (Mt. Triklario), Tcherna Cave (PAPADATou et al. 2011); Bella Voda, Mazi-Kirko, Sfika (PApadatou et al. 2013).

The common pipistrelle (Pipistrellus pipistrellus) is, along with the Kuhl's pipistrelle ( $P$. kuhlii), the most common bat species of the region. We registered it acoustically at 42 sites with 96 records (6.4-22.3\% of all echolocation recordings; Tables 4 and 5, Fig. 2H).

\section{Pipistrellus pygmaeus (Leach, 1825)}

Original Data. Agios Germanos: $200 \mathrm{~m} \mathrm{~W}$ of the village, 17 September 2018 - min. 1 ind. detected \& recorded. Karyes: $0.5-1 \mathrm{~km}$ E of the village, 17 September $2018-\min .1$ ind. detected \& recorded, 4 June 2019 - min. 2 inds. detected \& recorded; $300 \mathrm{~m} \mathrm{~S}$ of the village, 1 October $2020-\mathrm{min} .1$ ind. detected \& recorded; mountain pass $2.5 \mathrm{~km}$ E of the village, 18 September 2018 - min. 1 ind. detected $\&$ recorded. Kotas: $0.8 \mathrm{~km} \mathrm{~N}$ of the village, 18 September 2018 - min. 1 ind. detected \& recorded. Koula: 15 September 2018 - min. 1 ind. detected \& recorded; $1 \mathrm{~km}$ E of the site, 15 September 2018 - min. 1 ind. detected \& recorded; $0.5 \mathrm{~km} \mathrm{~S}$ of the site, 28 September $2020-\min .3$ inds. detected \& recorded; 29 September 2020 - min. 1 ind. detected \& recorded; 1 October 2020 - min. 1 ind. detected \& recorded; Prespa lake shore, 8 June 2019 - min. 1 ind. detected \& recorded. Krystallopigi: 30 September 2020 -

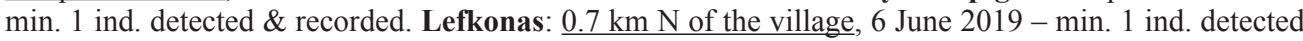
\& recorded; $1.5-2.5 \mathrm{~km} \mathrm{~S}$ of the village, 1 October $2020-\min .2$ inds. detected \& recorded. Lemos: 17 September 2018 - min. 1 ind. detected \& recorded; 1 October 2020 - several inds. detected \& recorded. Mikrolimni: up to Oxya village, 18 September 2018 - several inds. detected \& recorded. Milionas: $1 \mathrm{~km}$ $\underline{\mathrm{W}}$ of the village, 18 September 2018 - min. 1 ind. detected \& recorded; $2.2 \mathrm{~km} \mathrm{~W}$ of the village, 29 September 2020 - min. 1 ind. detected \& recorded. Oxya: 4 June 2019 - min. 1 ind. detected \& recorded; 0.5-1.8 km E of the village, 18 September 2018 - several inds. detected \& recorded; 4 June 2019 - min. 1 ind. detected \& recorded. Prasino: Ladopotamos river, 5 June 2019 - min. 1 ind. detected \& recorded. Pyli: $0.5 \mathrm{~km}$ E of the village, 16 September 2018 - min. 1 ind. detected \& recorded; 19 September 2018 - min. 1 ind. detected \& recorded; $1.5-2.2 \mathrm{~km}$ E of village, 28 September 2020 - min. 1 ind. detected $\&$ recorded; 29 September 2020 - min. 1 ind. detected \& recorded. Vrontero: 29 September 2020 - min. 1 ind. detected \& recorded.

Published data. Prespa region (Gremillet et al. 2010); Agios Germanos River (estuary), Bouskani, Kotas (Ladopotamos River), Latsista, Sfika ruins, Zachariadis Cave (PAPAdATou et al. 2011).

The soprano pipistrelle (Pipistrellus pygmaeus) was recorded almost over the whole region under study. Although this species is less frequent than other pipistrelle species, we registered it by 29 acoustic records at 24 sites (Fig. 2I).

\section{Pipistrellus kuhlii (Kuhl, 1817)}

Original Data. Karyes: 4 June 2019 - several inds. detected \& recorded; $0.5-1.5 \mathrm{~km}$ SE of the village, 4 June 2019 - several inds. detected \& recorded; $0.3-2.2 \mathrm{~km} \mathrm{NW}$ of the village, 4 June 2019 - several inds. detected \& recorded; $0.5-1.5 \mathrm{~km} \mathrm{~N}$ of the village, 6 June 2019 - several inds. detected \& recorded; mountain pass $1.8-2.5 \mathrm{~km}$ E of the village, 6 June 2019 - several inds. detected \& recorded. Koula: up to $3.5 \mathrm{~km}$ E of site, 4 June 2019 - several inds. detected \& recorded; $1-1.8 \mathrm{~km} \mathrm{~S}$ of the site, 4 June 2019 - several inds. detected \& recorded; Prespa lake shore, 8 June 2019 - many inds. detected \& recorded. Lefkonas: 4 and 6 June 2019 - min. 1 ind. detected \& recorded; $0.8-2 \mathrm{~km} \mathrm{~N}$ of village, 4 June 2019 - min. 1 ind. detected \& recorded. Mikrolimni: 4 June 2019 - several inds. detected \& recorded. Milionas: $1 \mathrm{~km}$ W of the village, 4 June 2019 - min. 1 ind. detected \& recorded. Oxya: 4 June 2019 - min. 1 ind. detected

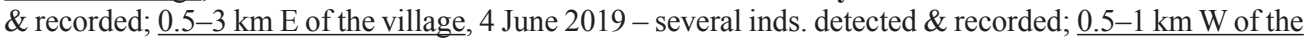
village, 4 June 2019 - several inds. detected \& recorded. Plati: $0.5 \mathrm{~km}$ W of village, 4 June $2019-\min$. 
1 ind. detected \& recorded. Prasino: $0.5-1.5 \mathrm{~km} \mathrm{~N}$ of the village, 6 June 2019 - min. 1 ind. detected \& recorded; Ladopotamos river, 5 June 2019 - several inds. detected \& recorded. Psarades: 30 June 2015 - several inds. detected \& recorded. Pyli: 4 June 2019 - several inds. detected \& recorded; $2-3 \mathrm{~km} \mathrm{E} \mathrm{of}$

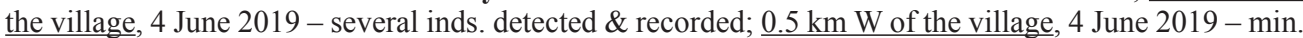
1 ind. detected \& recorded; $2.5 \mathrm{~km} \mathrm{~W}$ of the village, 4 June $2019-$ min. 1 ind. detected \& recorded. Sfika, 7 June 2019 - several inds. detected \& recorded. Trigono: $0.8 \mathrm{~km} \mathrm{NW}$ of the village, 6 June 2019 - min. 1 ind. detected \& recorded. Vrontero: 4 June 2019 - several inds. detected \& recorded; $\underline{0.5-1.5 \mathrm{~km} \mathrm{~S} \text { of }}$ the village, 4 June 2019 - several inds. detected \& recorded.

Published data: Agios Germanos River (ford), Psarades, Sfika (Mt. Triklario) (PAPADATOU et al. 2011); Sfika (PAPADATOU et al. 2013).

The Kuhl's pipistrelle (Pipistrellus kuhlii) is, similarly as two previous pipistrelle species ( $P$. pipistrellus and $P$. pygmaeus), a common and widespread bat in the region. We registered it during the summer survey (2019) by 28 call recordings from 27 sites (Fig. 2J). However, the abundance and frequency estimation of $P$. kuhlii is complicated during the autumn period, when another species, the Nathusius' bat, $P$. nathusii (von Keyserling et Blasius, 1839), could occur in the area more frequently than in other parts of a year (cf. vON HELVERSEN \& WEID 1990, HANÁK et al. 2001) and echolocation calls of the two species cannot be distinguished with certainty.

\section{Pipistrellus kuhlii/nathusii}

Original Data. Agios Germanos: 18 September 2018, 28-30 September 2020, 1 October 2020 - several inds. detected \& recorded. Karyes: 30 September 2020 - min. 1 ind. detected \& recorded; $0.5 \mathrm{~km} \mathrm{~S}$ of the village, 17 September 2018 - min. 1 ind. detected $\&$ recorded; $1.5 \mathrm{~km}$ E of the village, 18 September

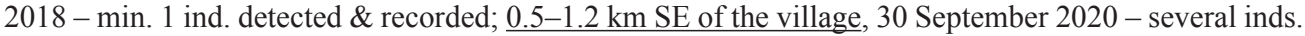

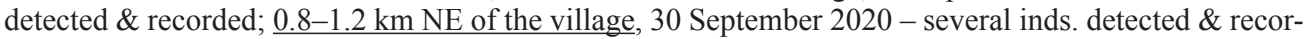
ded; up to $2.5 \mathrm{~km} \mathrm{~N}$ of the village, 1 October 2020 - many inds. detected \& recorded; $0.5-2.5 \mathrm{~km}$ E of the village, 1 October 2020 - many inds. detected \& recorded. Kotas: $1.6 \mathrm{~km} \mathrm{~N}$ of the village, 17 September 2018 - min. 1 ind. detected \& recorded; $0.8-1 \mathrm{~km} \mathrm{NE}$ of the village, 18 September 2018, 30 September 2020 - min. 1 ind. detected \& recorded. Koula: up to $2 \mathrm{~km} \mathrm{~S}$ of the site, 15 September 2018, 28 and 29 September 2020, 2 October 2020 - many inds. detected \& recorded; up to $3 \mathrm{~km}$ E of the site, 15 and 16 September 2018, 28 and 29 September 2020, 2 October 2020 - many inds. detected \& recorded;

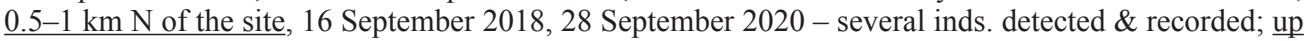
to Agios Georgios, 29 September 2020, 2 October 2020 - many inds. detected \& recorded. Krystallopigi: 17 September 2018, 30 September 2020 - several inds. detected \& recorded; $0.8-3.5 \mathrm{~km}$ NE of the village, 30 September 2020 - several inds. detected \& recorded. Lefkonas: 18 September 2018 - min. 1 ind. detected \& recorded; $1-1.5 \mathrm{~km} \mathrm{~N}$ of the village, 18 September 2018, 30 September $2020-\mathrm{min} .1$ ind. detected \& recorded; $0.8 \mathrm{~km} \mathrm{SW}$ of the village, 30 September 2020 - min. 1 ind. detected \& recorded; $0.5-2.5 \mathrm{~km} \mathrm{~N}$ of the village, 1 October 2020 - several inds. detected \& recorded. Lemos: 17 September

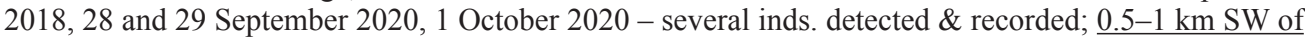
the village, 16 September 2018, 30 September 2020, 2 October 2020 - min. 1 ind. detected \& recorded;

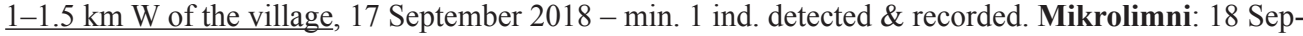

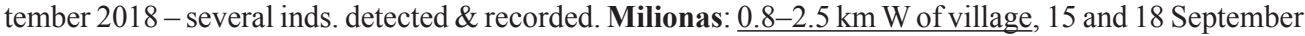
2018, 28-30 September 2020, 1 and 2 October 2020 - several inds. detected \& recorded; $300 \mathrm{~m} \mathrm{~N}$ of the village, 1 October 2020 - min. 1 ind. detected \& recorded. Oxya: $1 \mathrm{~km} \mathrm{NE}$ of the village, 18 September 2018 - min. 1 ind. detected \& recorded; up to $0.8 \mathrm{~km} \mathrm{NW}$ of the village, 18 September 2018 - several inds. detected \& recorded. Plati: 17 September 2018 - min. 1 ind. detected \& recorded; $\underline{0.5 \mathrm{~km} \text { W of the }}$ village, 17 and 18 September 2018, 30 September 2020, 1 October 2020 - several inds. detected \& recorded; $0.7-1.2 \mathrm{~km}$ NW of the village, 17 September 2018 - several inds. detected \& recorded; $1 \mathrm{~km} \mathrm{SW} \mathrm{of}$ the village, 17 September 2018 - min. 1 ind. detected \& recorded. Psarades: 15 and 16 September 2018, 


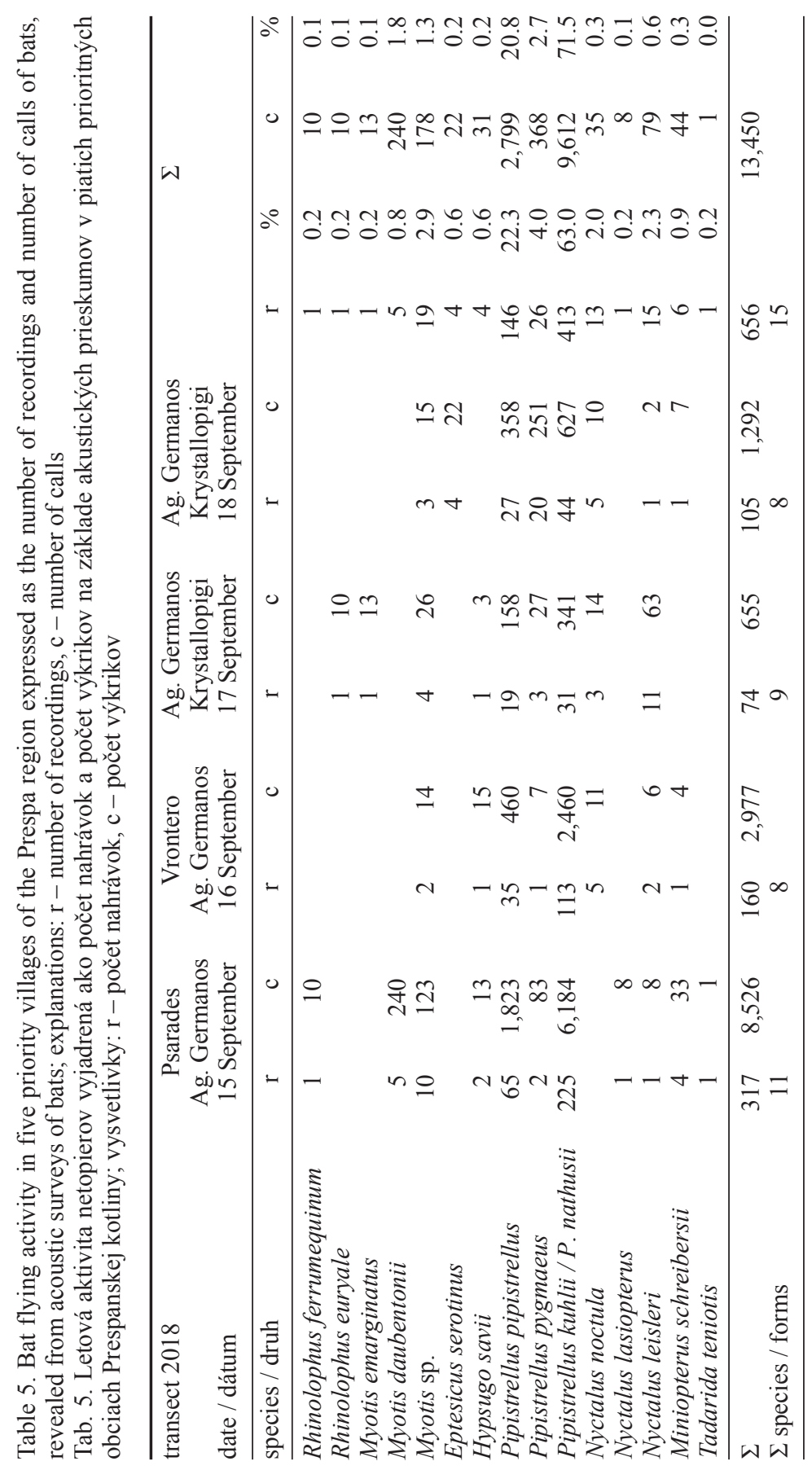




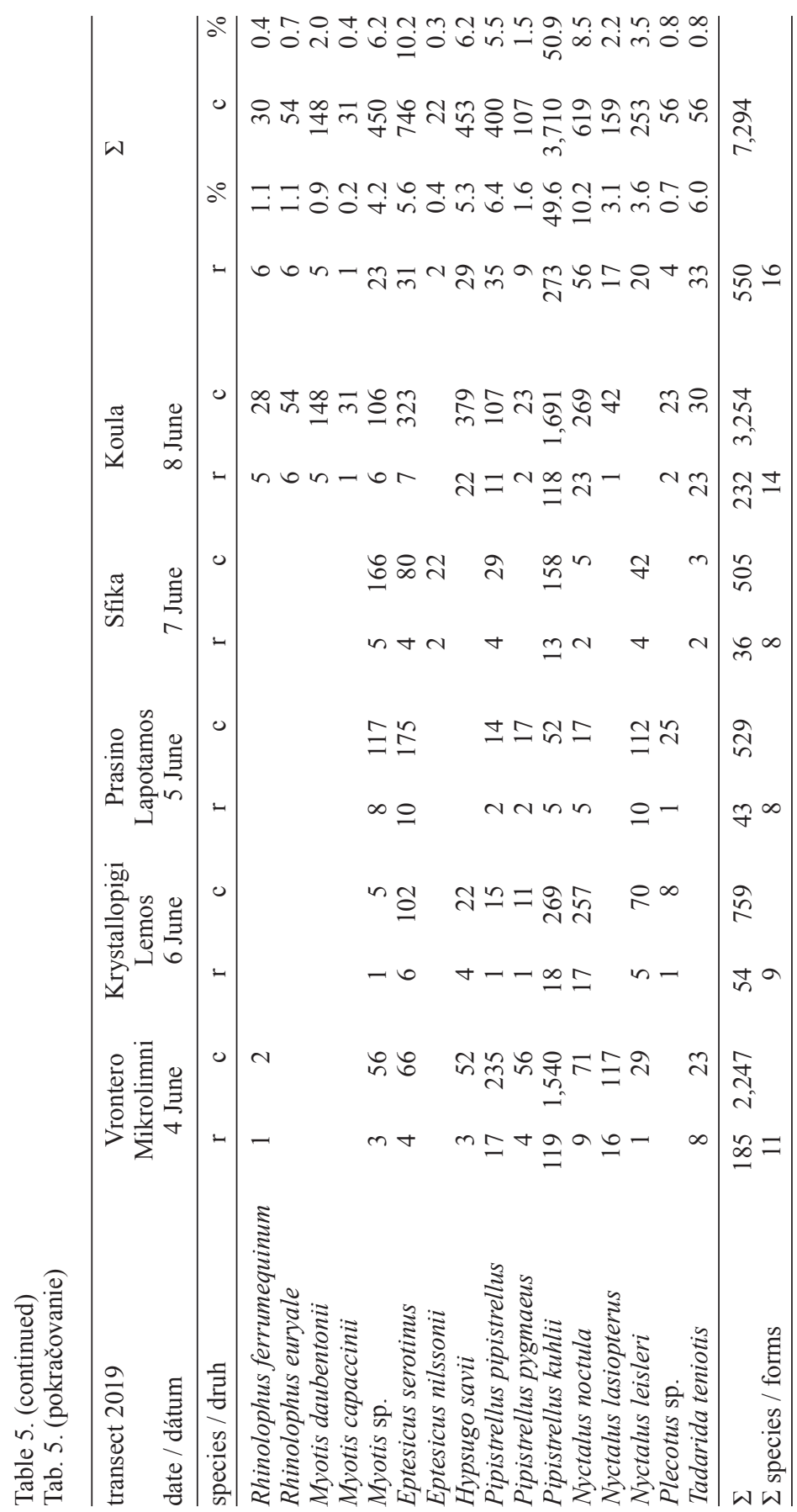




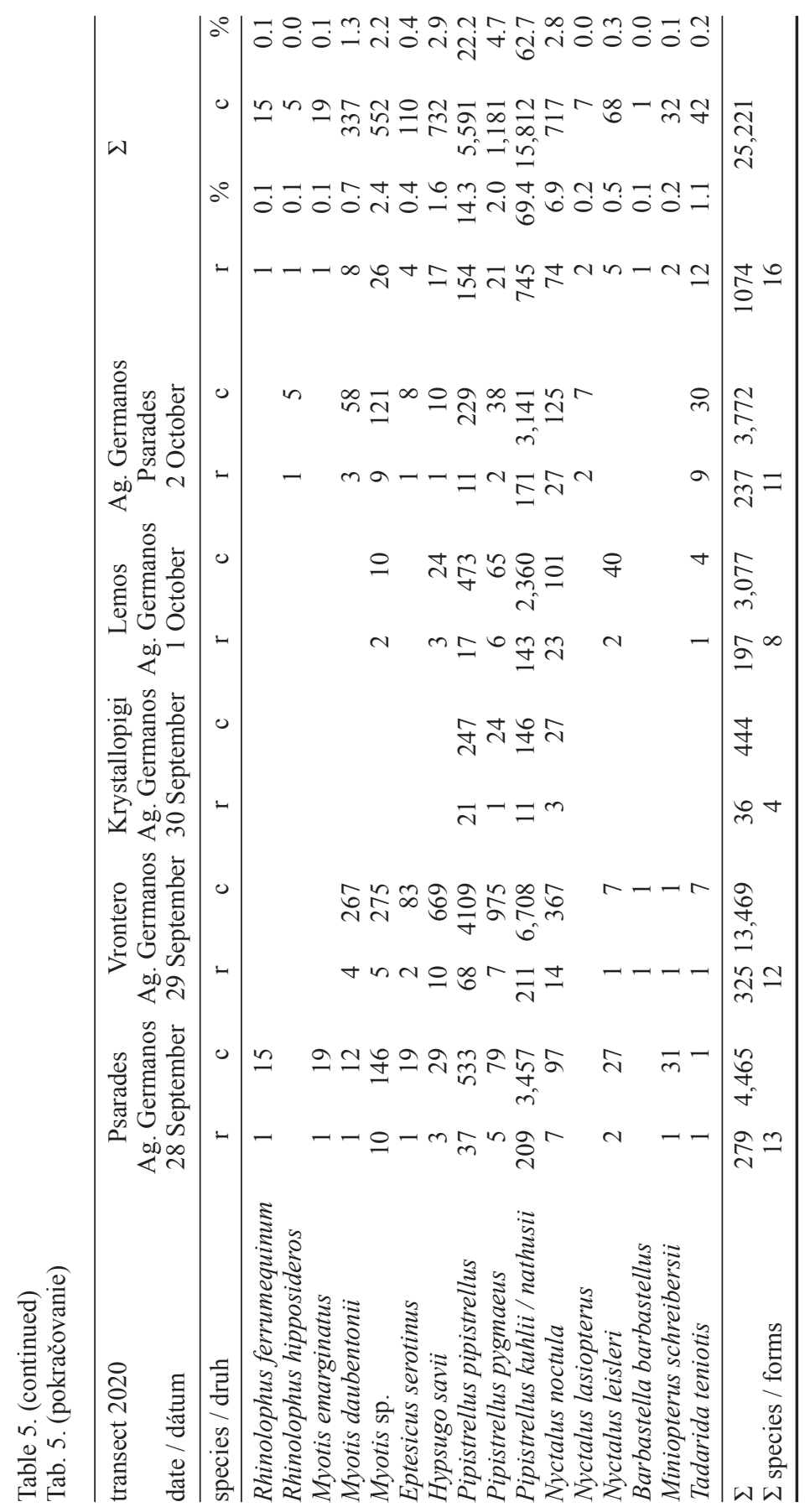


28 and 29 September 2020, 2 October 2020 - many inds. detected \& recorded; $1.5 \mathrm{~km} \mathrm{SE}$ of the village, 15 September 2018 - many inds. detected \& recorded; $0.5-1.5 \mathrm{~km}$ SE of the village, 16 September 2018 , 28 September 2020 - min. 1 ind. detected \& recorded; up to $2 \mathrm{~km} \mathrm{SE}$ of the village, 28 September 2020 - many inds. detected \& recorded; $0.3-1.2 \mathrm{~km} \mathrm{SE}$ of the village, 2 October 2020 - several inds. detected \& recorded; Agios Georgios, 15 and 16 September 2018, 28 September 2020 - several inds. detected $\&$ recorded; Cape Roti, 2 October 2020 - several inds. detected \& recorded. Pyli: 15, 16 and 19 September 2018, 28 and 29 September 2020, 2 October 2020 - several inds. detected \& recorded; $\underline{0.5-3 \mathrm{~km} \text { E of the }}$ village, 15 and 16 September 2018, 28 and 29 September 2020, 2 October 2020 - many inds. detected \& recorded; $0.5-3 \mathrm{~km} \mathrm{~W}$ of the village, 15 September 2018, 29 September 2020 - many inds. detected $\&$ recorded; $2-2.5 \mathrm{~km} \mathrm{~W}$ of the village, 16 September 2018 - min. 1 ind. detected \& recorded. Trigono: mountain pass $1-3.5 \mathrm{~km}$ E of the village, 17 September 2018 - several inds. detected \& recorded; $0.8 \mathrm{~km}$ $\underline{\mathrm{W}}$ of the village, 30 September 2020 - min. 1 ind. detected \& recorded; mountain pass $1.5-2.5 \mathrm{~km} \mathrm{E} \mathrm{of}$ the village, 1 October 2020 - several inds. detected \& recorded. Vatochori: $1.7 \mathrm{~km}$ E of the village, 30 September 2020 - min. 1 ind. detected \& recorded. Vrontero: 15 and 16 September 2018, 29 September 2020 - many inds. detected \& recorded; $2.5 \mathrm{~km} \mathrm{NW}$ of the village, 15 September $2018-\mathrm{min} .1$ ind. detected \& recorded; $2-4 \mathrm{~km} \mathrm{~N}$ of the village, 29 September 2020 - several inds. detected \& recorded.

The above listed records represent autumnal (September 2018,2020) acoustic evidences of bat calls, which belong to one of two species acoustically very similar to each other, Pipistrellus kuhlii and $P$. nathusii. Their calls cannot be identified to the species level with certainty. The migratory latter species occurs in the Prespa region frequently only in the autumn period (see e.g., von Helversen \& Weid 1990, Hanák et al. 2001, PApadatou et al. 2011), therefore the autumnal call evidence is not assigned to either of this species pair. Nevertheless, these calls appear to be the most common and frequent in the region; this form (one unidentifiable species or a pair of species) was registered by 99 acoustic recordings at 50 sites (Fig. 2K) with the dominancy of $63.0-69.4 \%$ of all recorded bat calls (see Tables 4 and 5). Perhaps a better picture of proportions among pipistrelle species could be provided by the solely summer sample (when migratory $P$. nathusii are mostly missing in the region). During the surveys in June $2019, P$. kuhlii was the most common (49.6\%), followed by P. pipistrellus $(6.4 \%), H$. savii $(5.3 \%)$, and P.pygmaeus (1.6\%; for details see Table 5).

\section{Nyctalus noctula (Schreber, 1774)}

ORIGINAL DATA. Karyes: 4 and 6 June 2019 - min. 2 inds. detected \& recorded; $1 \mathrm{~km} \mathrm{SE}$ of the village, 18 September 2018 - min. 1 ind. detected \& recorded; $0.5-1 \mathrm{~km} \mathrm{NW}$ of the village, 4 June 2019 - min. 1 ind. detected \& recorded; $1 \mathrm{~km}$ SE of the village, 4 and 6 June $2019-\min .1$ ind. detected \& recorded. Kotas: 1 Ocotber 2020 - min. 1 ind. detected \& recorded; $1.5 \mathrm{~km} \mathrm{~S}$ of village, 1 Ocotber 2020 - min. 1 ind. detected \& recorded; $1-2 \mathrm{~km}$ NE of village, 17 September 2018, 6 June $2019-\mathrm{min} .1$ ind. detected \& recorded. Koula: 4 June 2019, 28 and 29 September 2020 - min. 1 ind. detected \& recorded; $1 \mathrm{~km} \mathrm{~S} \mathrm{of}$ the site, 29 September 2020 - min. 1 ind. detected \& recorded; $2.2 \mathrm{~km}$ E of the site, 29 September 2020 , 2 October 2020 - min. 1 ind. detected \& recorded; Prespa lake shore, 8 June 2019 - several inds. detected \& recorded. Krystallopigi: 17 September 2018, 30 September 2020 - min. 1 ind. detected \& recorded.

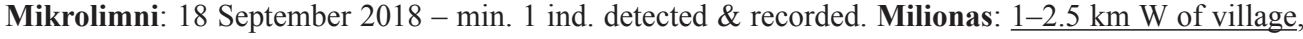
29 September 2020, 1 and 2 October 2020 - min. 1 ind. detected \& recorded. Lefkonas: 6 June 2019 min. 1 ind. detected \& recorded; $0.5-1.2 \mathrm{~km} \mathrm{~N}$ of village, 18 September 2018, 1 October 2020 - min. 1 ind. detected \& recorded; $1.5-2.5 \mathrm{~km} \mathrm{~S}$ of the village, 1 October $2020-\min .1$ ind. detected \& recorded. Lemos: $1 \mathrm{~km} \mathrm{SW}$ of the village, 28 September 2020, 1 October $2020-$ min. 1 ind. detected \& recorded. Oxya: 18 September $2018-$ min. 1 ind. detected \& recorded. Plati: $1 \mathrm{~km} \mathrm{~S}$ of the village, 17 September 2018 - min. 1 ind. detected \& recorded; $0.5 \mathrm{~km} \mathrm{~W}$ of the village, 6 June 2019, 1 October 2020 - min. 1 ind. detected \& recorded. Prasino: $0.5-2 \mathrm{~km} \mathrm{SW}$ of the village, 1 October $2020-\mathrm{min} .1$ ind. detected 
\& recorded; Ladopotamos river, 5 June 2019 - several inds. detected \& recorded. Psarades: 28 September 2020, 2 October 2020 - several inds. detected \& recorded. Pyli: 28 September 2020, 2 October 2020 - several inds. detected \& recorded; $1.5-3.5 \mathrm{~km}$ E of the village, 4 June $2019-\mathrm{min} .2$ inds. detected \& recorded; $0.5-3 \mathrm{~km}$ E of the village, 2 October 2020 - several inds. detected \& recorded. Sfika, 7 June 2019 - min. 1 ind. detected \& recorded. Trigono: mountain pass $1-3.5 \mathrm{~km}$ E of the village, 6 June 2019 , 1 October 2020 - several inds. detected \& recorded; $0.5 \mathrm{~km} \mathrm{SW}$ of the village, 1 October 2020 - min.

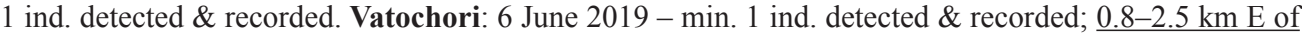
the village, 6 June 2019, 30 September 2020, 1 October 2020 - min. 2 inds. detected \& recorded; $1.2 \mathrm{~km}$ $\mathrm{W}$ of the village, 6 June 2019 - min. 1 ind. detected \& recorded. Vrontero: 16 September 2018, 29 September 2020 - several inds. detected \& recorded.

Published data. Prespa region (Gremillet et al. 2010); Agios Germanos River (estuary), Bella Voda (Mt. Varnous), Mazi-Kirko (Mt. Varnous), Moutsara (Mt. Varnous), Mt. Devas 2, Psarades (PAPAdAtou et al. 2011); Bella Voda, Mazi-Kirko, Moutsara (PAPADatou et al. 2013).

The common noctule (Nyctalus noctula) is the most common and widespread species of the three species of the genus Nyctalus in the region. We recorded it acoustically all over the region from lower positions up to the highest surveyed places, for example at the abandoned village of Sfika (ca. 1,220 m a. s. 1.; Fig. 2M). The breeding status of the species is not clear, males are most possibly present year-round, whereas females may be present only in the colder part of a year, from late summer and autumn to spring (PAPADATOU et al. 2011).

\section{Nyctalus lasiopterus (Schreber, 1780)}

Original Data. Karyes: 4 June 2019 - min. 1 ind. detected \& recorded; $1 \mathrm{~km}$ SE of the village, 4 June 2019 - min. 1 ind. detected \& recorded. Koula: up to $2 \mathrm{~km}$ E of the site, 4 June 2019 - several inds. detected \& recorded; Prespa lake shore, 8 June 2019 - min. 1 ind. detected \& recorded. Lefkonas: $1.6 \mathrm{~km}$ $\mathrm{S}$ of the village, 4 June $2019-\min .1$ ind. detected \& recorded. Plati: $0.5 \mathrm{~km} \mathrm{~W}$ of the village, 4 June 2019 - min. 1 ind. detected \& recorded. Psarades: 15 September $2018-$ min. 1 ind. detected \& recorded. Pyli: $\underline{300 \mathrm{~m} \text { E of the village, } 2 \text { October } 2020 \text { - min. } 1 \text { ind. detected \& recorded. Vrontero: } 3 \mathrm{~km} \mathrm{NW} \text { of }}$ the village, 4 June 2019 - min. 1 ind. detected \& recorded.

The greater noctule bat (Nyctalus lasiopterus) is reported here from the Prespa region for the first time, this species has not been listed as a member of the regional bat fauna so far (PAPADATOU et al. 2011). We registered echolocation calls of this species in all seasons (2018-2020) by nine recorders situated at nine sites (Fig. 2N). However, this discovery is not suprising, previous reliable data suggested the whole territory of mainland Greece as a part of the range of this species (HANÁK et al. 2001), the species was also reported from the Albanian part of the wider Prespa region (BENDA et al. 2019). Nevertheless, the occurrence and status of $N$. lasiopterus in the Prespa region requires confirmation by capture or at least direct observation of an individual.

\section{Nyctalus leisleri (Kuhl, 1817)}

Original DATA. Kotas: $1.7-2.5 \mathrm{~km} \mathrm{~S}$ of the village, 17 September 2018 - min. 1 ind. detected \& recorded; $1 \mathrm{~km} \mathrm{NE}$ of the village, 18 September 2018 - min. 1 ind. detected \& recorded. Krystallopigi: 17 September 2018 - several inds. detected \& recorded; $6 \mathrm{~km}$ E of the village, 17 September 2018 - min. 1 ind. detected $\&$ recorded. Lefkonas: $1.2 \mathrm{~km} \mathrm{~N}$ of the village, 6 June 2019 - min. 1 ind. detected \& recorded. Milionas: $1-1.5 \mathrm{~km}$ W of village, 29 September and 1 October 2020 - min. 1 ind. detected \& recorded. Prasino: $1-1.2 \mathrm{~km} \mathrm{SW}$ of the village, 17 September 2018 - min. 1 ind. detected \& recorded; 1 October 2020 - min. 1 ind. detected \& recorded; Ladopotamos river, 5 June 2019 - several inds. detected \& recorded. Psarades: 28 September 2020 - min. 1 ind. detected \& recorded; Agios Georgios, 15 September 2018 - min. 1 ind. 

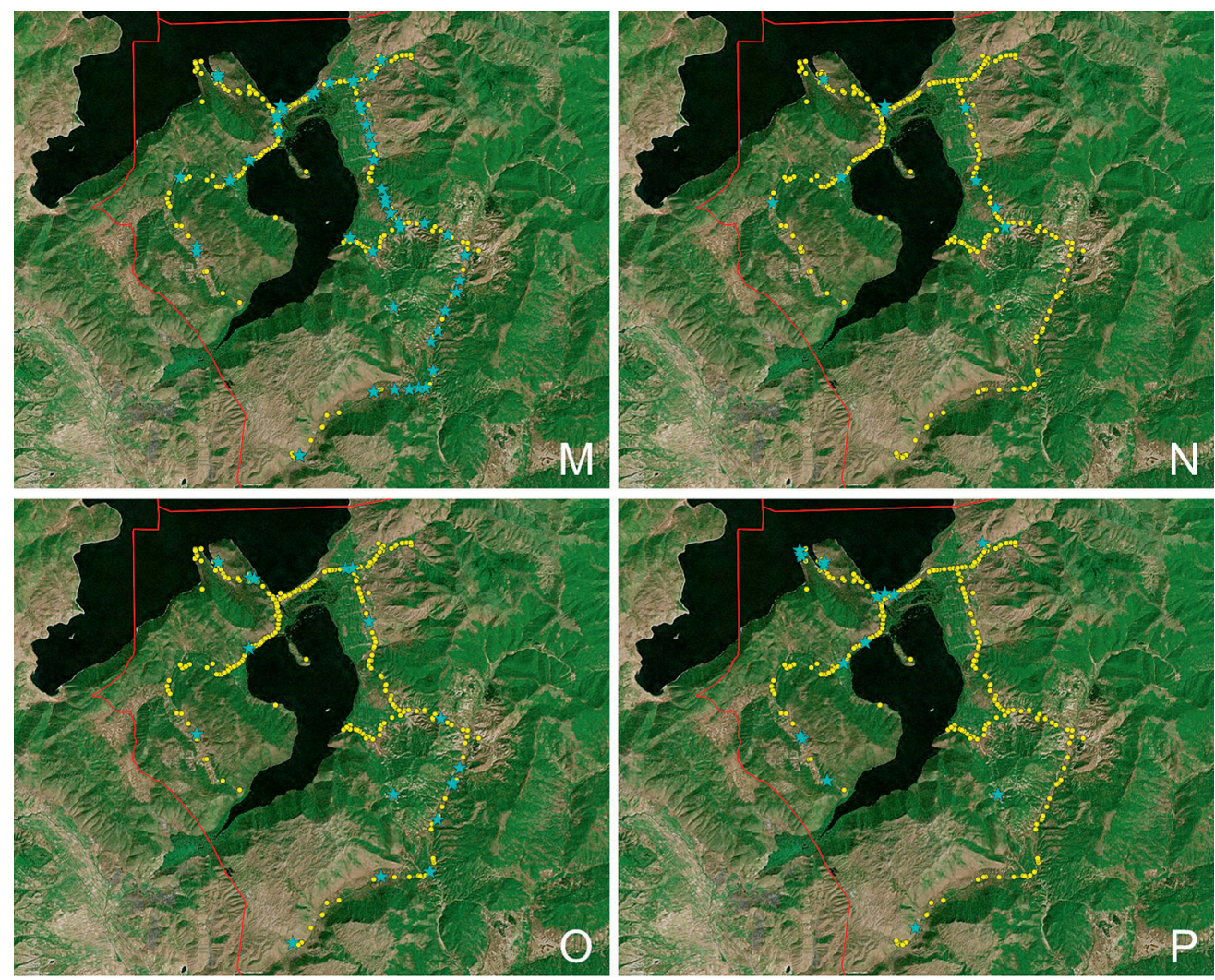

Fig. 2. (continued)

Obr. 2. (pokračovanie)

$\mathrm{M}$ - Nyctalus noctula, $\mathrm{N}$ - Nyctalus lasiopterus, $\mathrm{O}$ - Nyctalus leisleri, $\mathrm{P}$ - Tadarida teniotis.

detected \& recorded; 28 September 2020 - min. 1 ind. detected \& recorded. Pyli: $1.5 \mathrm{~km}$ E of the village, 4 June 2019 - min. 1 ind. detected \& recorded. Sfika, 7 June 2019 - several inds. detected \& recorded. Trigono: mountain pass 1-2.5 km E of the village, 6 June 2019 - min. 1 ind. detected \& recorded. Vrontero: 16 September 2018 - min. 2 inds. detected \& recorded.

Published data. Agios Germanos River (ford), Kotas (Ladopotamos River), Mazi-Kirko (Mt. Varnous), Sfika ruins, Zachariadis Cave (Papadatou et al. 2011); Mazi-Kirko (Papadatou et al. 2013).

The lesser noctule (Nyctalus leisleri) belongs to less distributed but regularly occurring bat species of the region. We registered it acoustically by 17 recordings at 14 sites (Fig. 2O), which represents $0.5-3.6 \%$ of all echolocation recordings (Tables 4 and 5).

\section{Barbastella barbastellus (Schreber, 1774)}

Original data. Koula: 29 September 2020 - min. 1 ind. detected \& recorded. 
The western barbastelle (Barbastella barbastellus) is here reported from the Prespa region for the first time, this species has not been listed among the members of local bat fauna so far (PAPADATOU et al. 2011; Fig. 2L). Considering its status of a rare bat in the whole Greece (HANÁK et al. 2001), the regional status in the Prespa region requires confirmation by capture or at least direct observation of an individual. In Albania, the species has been recently reported from several sites including the wider vicinity of the Ohrid lake as the nearest site to the Prespa region (BENDA et al. 2019). Albanian records, together with our evidence from Prespa, could represent a significant extension of the distribution range of the species in south-eastern Europe compared to the pattern of the previously reconstructed range in the Ballkans (PAUNOVIC et al. 2003).

\section{Plecotus austriacus (Fischer, 1829)}

Original data. Psarades: Hermitage of Metamorphosis, cliffs, 18 September $2018-2$ inds. obs. in fissures; 8 June 2019 - 1 ind. obs. in the same fissure. Vrontero: Kokkalis cave, 29 September 2020 -1 ind. obs.

Published data. Pyli (Hanák et al. 2001); Kokkalis Cave (Papadatou et al. 2011).

We made only three records of the grey long-eared bat (Plecotus austriacus), all in cave roosts (Fig. 2L), i.e., in a small cave near Hermitage of Metamorphosis and in Kokkalis cave. From the latter site this species was reported also by the previous study (PAPADATOU et al. 2011).

\section{Plecotus sp.}

Original Data. Koula: Prespa lake shore, 8 June 2019 - min. 1 ind. detected \& recorded. Prasino: Ladopotamos river, 5 June 2019 - min. 1 ind. detected \& recorded.

Two acoustic records of the long-eared bat calls, which could not be assigned to a particular species of the genus Plecotus, just supplement the picture of bat activity recorded in summer 2019 in the region. In general, three species of this genus could be considered to occur in the region: along with $P$. auritus and $P$. austriacus, recorded already by the previous surveys in the Greek part of the region (HANÁK et al. 2001, PAPADATOU et al. 2011), also P. kolombatovici could be present there. The latter species has been recently reported from the Treni cave situated on the Albanian shore of the Mikri Prespa lake, just few kilometres from the Greek state border (SCHEFFLER et al. 2013, TheOU et al. 2015a).

\section{Miniopterus schreibersii (Kuhl, 1817)}

Original data. Koula: $300 \mathrm{~m} \mathrm{~S}$ of the site, 28 September 2020 - min. 1 ind. detected \& recorded; $600 \mathrm{~m}$ $\underline{\mathrm{S}}$ of the site, 29 September 2020 - min. 1 ind. detected \& recorded. Milionas: $1 \mathrm{~km} \mathrm{~W}$ of the village, 15 September 2018 - min. 1 ind. detected \& recorded. Oxya: $1 \mathrm{~km}$ E of the village, 18 September 2018 - min. 1 ind. detected \& recorded. Pyli: $2.8 \mathrm{~km} \mathrm{~W}$ of the village, 15 September 2018 - min. 3 inds. detected \& recorded. Psarades: Tcherna cave, 20 September 2018 - 1 mummified ind. found; 1 October 2020 - a colony of ca. 200 inds. obs. Vrontero: $1 \mathrm{~m} \mathrm{~N}$ of the village, 16 September 2018 - min. 1 ind. detected \& recorded.

Published data. Bella Voda (Galand et al. 2010, Vrahnakis et al. 2010); Prespa region (Gremillet et al. 2010); Agios Achilleos, Agios Germanos, Agios Germanos River (estuary), Agios Germanos River (ford), Agios Germanos (mill), Bella Voda (Mt. Varnous), Kokkalis Cave, Koula, Krina, Mazi-Kirko (Mt. Varnous), Mt. Devas 1, Mt. Devas 2, Sfika (Mt. Triklario), Sfika ruins, Tcherna Cave (PAPAdAtou et al. 2011); Bella Voda, Mazi-Kirko, Sfika (Papadatou et al. 2013). 
The European bent-wing bat (Miniopterus schreibersii) was registered at seven sites by six acoustic and two roost-based records during our survey (Fig. 2L). In autumn 2020, we confirmed presence of the previously discovered large colony in the Tcherna cave (PAPADATOU et al. 2011).

\section{Tadarida teniotis (Rafinesque, 1814)}

ORIGINAL DATA. Koula: 15 September 2018 - min. 1 ind. detected \& recorded; 4 June 2019; Prespa lake shore, 8 June 2019 - several inds. detected \& recorded and voice registered by ear. Krystallopigi: $\underline{N \text { of }}$ the village, 6 June 2019 - voice registered by ear. Lemos: 8 June 2019 - several voices registered by ear. Psarades; 30 June 2015 - several inds. detected \& recorded; 28 September 2020 - min. 1 ind. detected $\&$ recorded; Hermitage of Metamorphosis, rocky fissure S of the site, 30 September 2020 - 4 inds. obs.; Hermitage of Metamorphosis, rocky fissure $\mathrm{N}$ of the site, 30 September 2020 - 1 ind. obs.; Tcherna cave, rocky fissures near a small cave S of the site, 1 October 2020 - voices of several inds. Pyli: 2 October 2020 - min. 1 ind. detected \& recorded; $2.2 \mathrm{~km}$ E of the village, 2 October 2020 - min. 2 inds. detected \& recorded. Sfika: 6 June 2019 - voice registered by ear; 7 June 2019 - several inds. detected \& recorded. Vrontero: 4 June 2019 - voice registered by ear; 29 September, 2 October 2020 - min. 1 ind. detected $\&$ recorded.

Published data. Bella Voda (Galand et al. 2010, Vrahnakis et al. 2010); Prespa region (Gremillet et al. 2010); Agios Achilleos, Agios Germanos River (estuary), Bella Voda (Mt. Varnous), Cape Roti (western shore), Giaintsa, Mazi-Kirko (Mt. Varnous), Metamorphosi Hermitage (rocky shore), Mikrolimni, Mikrolimni (quarry), Panagia Eleousa Hermitage, Psarades/Agios Nikolaos, Tcherna Cave (PAPADAtou et al. 2011); Bella Voda, Mazi-Kirko (Papadatou et al. 2013).

The European free-tailed bat (Tadarida teniotis) appears to be a common and widespread bat species in the region, during our survey, 16 acoustic and two roost records were made (Fig. 2P). The species was recorded regularly during car-based transects and often also thanks to its strong audible voice. The recorded pattern of regional occurrence is in concordance with the previously reported view (PAPADATOU et al. 2011).

\section{Negative roosts checks}

Original Data. Koula, abandoned restaurant, 15 September 2018 - some bat pellets obs. Krystallopigi, Moschochóri ruins, 17 September 2018 - no record. Lemos, abandoned building, 16 September 2018 - no record. Mikrolimni, Agios Paraskeri church, 16 September 2018 - bat pellets on the veranda. Mikrolimni, Kranies ruins, 19 September 2018 - no record. Oxya, new church at cemetery, 16 September 2018 - no record. Pyli, Agios Nicolaos, 17 September 2018 - no record. Pyli, Zachariadis cave, 5 June 2019 - no record. Plati, Agios Nicolaos, 17 September 2018 - no record. Psarades, Hermitage of Metamorphosis, 18 September 2018, 30 September 2020 - no record; cave N of the site, 20 September 2020 - no record. Psarades, Roti cave, 20 September 2018 - no record. Psarades, small cave S of the Tcherna cave, 1 October 2020 - no record. Vrontero, three abandoned school buildings, 16 September 2018 - no record.

Faunistic evaluation

Altogether, 26 bat species were recorded before the current study in the Greek part of the Prespa region (Table 3) which refers to a high bat diversity compared to other regions of the country (cf. HANÁK et al. 2001). During the surveys conducted in September 2018, June 2019, and September 2020, at least 20 bat species were recorded, among them three species - Eptesicus nilssonii, Nyctalus lasiopterus, and Barbastella barbastellus - that were not previously 
reported from the region (cf. PAPADATOU et al. 2011). One of these species (Eptesicus nilssonii) is here newly reported for the whole territory of Greece. However, all these records are based on the acoustic evidence only, thus the confirmation of the occurrence in the region should be documented by a catch or at least by observation of an animal. Despite this methodological limit, the recorded bat diversity in the region has increased to 29 species. Nevertheles, even the short field study presented in this report confirmed ca. $77 \%$ of the whole bat fauna of the region. We confirmed permanent favourable status of two of the important cave bat roosts in the region, the Mikrolimni cave (with a recorded colony of hundreds of Rhinolophus euryale) and Tcherna cave (with recorded aggregations of Rhinolophus ferrumequinum, $R$. hipposideros, Myotis capaccinii, and Miniopterus schreibersii). Further records, worth of mention, are several colonies of Rhinolophus hipposideros found mostly in abandoned old churches.

Acoustic surveys: species composition and abundance

Altogether, at least 21 bat species and/or species combinations (forms) were recorded during the acoustic surveys in prioritized villages, i.e., on four car-based transects and on three stationary

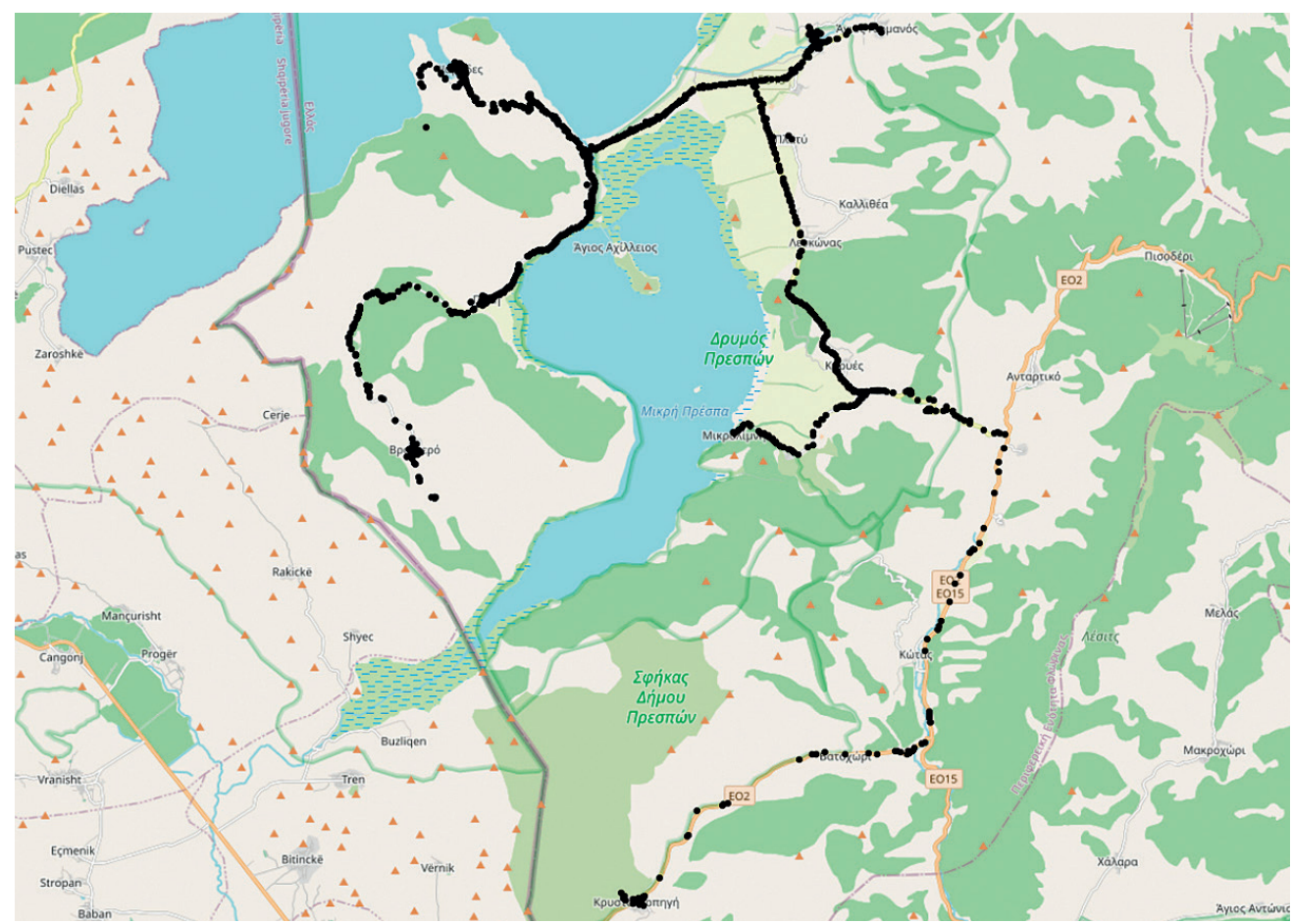

Fig. 3. Density of the relative flying activity of bats based on all records of all forms from all acoustic transects conducted in the Prespa region in 2018-2020.

Obr. 3. Hustota relatívnej letovej aktivity netopierov zobrazená na základe údajov z akustických transektov a všetkých záznamov všetkých foriem netopierov Prespanskej kotliny v období 2018-2020. 
sites (for details see Tables 4 and 5). Pipistrellus kuhlii/nathusii with 63.0\% and 69.4\%, respectively, of all recordings was the most abundant and most frequent bat form in the autumn seasons of 2018 and 2020. This eudominant form was followed by Pipistrellus pipistrellus with the dominancy of $22.5 \%$ and $14.3 \%$ in the autumn of 2018 and 2020, respectively. Nyctalus noctula was recorded as more abundant (10.2\%) during the summer (June 2019) transects than in the autumn seasons, when it can be considered as less abundant species $(2.0$ and $6.9 \%$, respectively). Nine forms with the seasonal recordings dominance exceeding $1 \%$ were recorded, i.e. Rhinolophus ferrumequinum and R. euryale (1.1\% each in summer 2019 only), Myotis sp. (2.4-4.2\%), Eptesicus serotinus (0.4-5.6\%), Hypsugo savii (0.6-5.3\%), P. pygmaeus (1.6-4.0\%), Nyctalus lasiopterus $(0.2-3.1 \%)$, N. leisleri $(0.5-3.6 \%)$, and Tadarida teniotis $(0.2-6.0 \%)$. All other species could be considered as accesoric elements of the recorded bat foraging community.

The highest number of forms (11-13; Table 4) was recorded on the transect Psarades - Pyli - Vrontero - Agios Germanos; only the Koula stationary site had more recorded forms (in total 14). This is in accordance with the general pattern revealed from all transects, where the relative density of bat foraging activity of all forms together decreases with increasing distance from the Prespa lake (Fig. 3). Most probably, this is related to a high level of prey availability above the water surface and near the lake shores.

When considering bat autumn flight acitivity only in the surveyed priority villages (Krystallopigi, Lemos, Pyli, Psarades, Vrontero), the highest values (number of forms 8 and 11, number of recordings 31-165) were observed in the villages near the lake shores (Psarades, Pyli; Table 4) which corroborates with the lake-distance relationship as mentioned above. The highest number of eight forms was observed in Krystallopigi, i.e., a site rather distant from the lake, however, the bat acivity was considerably low there, similarly as observed in the other two villages, Lemos and Vrontero. The activity of bats in a village is in general related to: (1) a presence of suitable roosts in urban structures of the village, and (2) a behaviour based on prey activity, particularly insects concentrated around street lamps as documented elsewhere (e.g., HAFFNER \& STUTZ 1985, Rydell 1992, Acharya \& Fenton 1999, Eisenbeis 2006). Anyway, we did not observe foraging bats directly in the light cones of the inspected lamps and thus, the direct correlation between current lighting and bat activity needs to be evaluated in more detail. In each of the villages we identified "dark" zones with lower values of the illumination (see also below).

\section{Light pollution assessment}

We compared five surveyed villages between each other and separately after two-year monitoring for the intensity of the Artificial Light at Night (ALAN; Table 6, Fig. 4). The localizations of georeferenced measuring points, established in 2018, had high accuracy in 2020 (3.79 m on average). The lowest maximum value of intensity of illuminance was recorded in Pyli during both years (2018: $\max =6.031 x ; 2020: \max =10.061 x$ ), followed by Vrontero, where during the second year of monitoring this value was only $10.05 \mathrm{~lx}$. The situation in this village is worth of mention, because in 2018 the maximum illuminance value was around $8 \times$ higher $(\mathrm{max}=86.60 \mathrm{~lx})$ and it represented the highest maximum value measured during this year of survey. In this view, we noticed that a strong halogene lamp at the NW edge of Vrontero represented a significant source of night lighting during the first year, but during the subsequent survey in 2020 we recorded several halogene lamps in this part of the village which were not working and therefore this change was probably the main explanatory reason for the recorded differences in values in 
Table 6. Intensity of the Artificial Light At Night (ALAN) as revealed from the light pollution surveys in five priority villages of the Prespa region $(2018,2020)$

Tab. 6. Intenzita umelého svetla v noci (ALAN) na základe prieskumu svetelného znečistenia v piatich prioritných obciach Prespanskej kotliny $(2018,2020)$

\begin{tabular}{lrrrrrrrrrr}
\hline village / obec & \multicolumn{2}{c}{ Krystallopigi } & \multicolumn{2}{c}{ Lemos } & \multicolumn{2}{c}{ Psarades } & \multicolumn{2}{c}{ Pyli } & \multicolumn{2}{c}{ Vrontero } \\
\hline year / rok & 2018 & 2020 & 2018 & 2020 & 2018 & 2020 & 2018 & 2020 & 2018 & 2020 \\
values / hodnoty & 32 & 40 & 41 & 45 & 15 & 15 & 16 & 17 & 16 & 16 \\
\hline min & 0.05 & 0.14 & 0.06 & 0.15 & 0.10 & 0.07 & 0.04 & 0.06 & 0.04 & 0.06 \\
max & 38.60 & 123.10 & 74.70 & 56.10 & 15.82 & 13.14 & 6.03 & 10.06 & 86.60 & 10.05 \\
mean / priemer & 3.74 & 9.06 & 4.08 & 5.41 & 3.18 & 3.24 & 1.05 & 2.03 & 6.93 & 2.83 \\
median & 0.88 & 2.59 & 1.50 & 1.59 & 1.06 & 0.53 & 0.51 & 0.86 & 1.02 & 1.96 \\
SD & 7.31 & 20.80 & 11.59 & 9.80 & 4.24 & 4.33 & 1.54 & 2.64 & 21.33 & 3.14 \\
\hline
\end{tabular}

this village. On the other hand, after the second-year light intensity measurement, Krystallopigi showed a significant increase in the maximum value $(\max =123.10 \mathrm{~lx}$ in 2020$)$ which was more than three times higher than in the previous year $(2018$ : $\max =38.60 \mathrm{~lx})$. The lowest minimum values were a little bit higher during the second year of the monitoring in all villages (2018: 0.04-0.10 lx; 2020: 0.60-0.15 lx), but these changes were not statistically significant. Maximum high values in Krystallopigi, Lemos, Psarades, and Pyli represented measurements conducted directly under the lamps with strong source or in their close proximities (e.g. Krystallopigi: 2018 - church lamp, 2020 - "bat friendly" lamp; Lemos: 2018, 2020 - lamp in the center of the village, Psarades: 2018, 2020 - port lamp, Vrontero: 2018 - a strong halogene lamp at the NW edge of the site; see also Fig. 6). Furthermore, in Krystallopigi in 2018 we observed that a church lamp with the highest intensity was an important light source. However, in the second year, we found that two lamps in this village with a more "bat friendly" construction were even higher in their intensity with 123.10 lx measured directly under the first lamp and $55.50 \mathrm{~lx}$ ca. $2.5 \mathrm{~m}$ far from the second lamp. Thus, these two lamps represented light sources with the highest intensity in this village during the second year of monitoring. The mean values follow the situation of maximum values in the above mentioned villages, whereas Lemos, Psarades and Pyli were more or less without significant changes (Table 6).

In general, the lowest ALAN values represented measurement points in "dark" parts of the villages with no lights or with not working lamps, whereas higher values were measured directly under the lamps or in various distances from the nearest lamps. The comparison of values from different parts of all villages (2018: 120 measurements, 2020: 133 measurements) showed higher mean values of light intensity in the second year of the monitoring (mean $=5.52 \mathrm{~lx}$ ) than during the first year of the survey (mean=3.85 lx). Only 15 measurements $(12.5 \%)$ from 2018 and 7 measurements $(5.26 \%)$ from 2020 fell into the group of values smaller than or equal to $0.1 \mathrm{~lx}$, which represent natural conditions without any artificial light and with typical full moon levels ( $\sim .1 \mathrm{~lx})$ as innate light levels and for which bats (and other organisms) are more or less evolutionary adapted (SHEN et al. 2010, Voigt et al. 2018b; Fig. 5).

In the villages monitored in both years of the survey, we observed lamps with light sources of various intensity, at different heights above the ground, lamps of various shapes and also light colours (Fig. 6). Except some lamps with very strong light intensity, we recorded streets where e.g. only a half of the lamp number was working (Fig. 6E). Some lamps were switched off, 
some had a broken cover and many of the working lamps lacked cover which increased their illuminance intensity. The latter situation was usually the case of very high lamps with yellow light (Fig. 6H). This lamp type represents a significant part of night lighting in all villages. Further important light sources are ball lamps with various light colour usually with cover but of various shades (from translucent through white) and thus, with a various permeability of light. These lamps are not so high than the previous type (Fig. 6G). We also registered two lamps of a special type in Krystallopigi. They had a construction which prevented light transmission upwards, but downwards we noticed a strong light intensity when measured directly under them or several meters from them (Fig 6D). Hovewer, all other lamps installed in the villages under study did not have any luminaries and produced light in all directions, not only on the streets, thus all lamps supported negative light trespass to adjacent habitats and/or to the sky.

Higher illumination intensity in Krystallopigi during the second period presented as the heatmap is evident from Fig. 7. During the first monitoring season, bats were active in the northwestern part of the village mostly close to the lights with low illumination intensity. High bat activity was observed in the central part of the village in the proximity of the lamps with high illumination but still in the peripheral parts of this zone. Bats were active also on the outskirts of

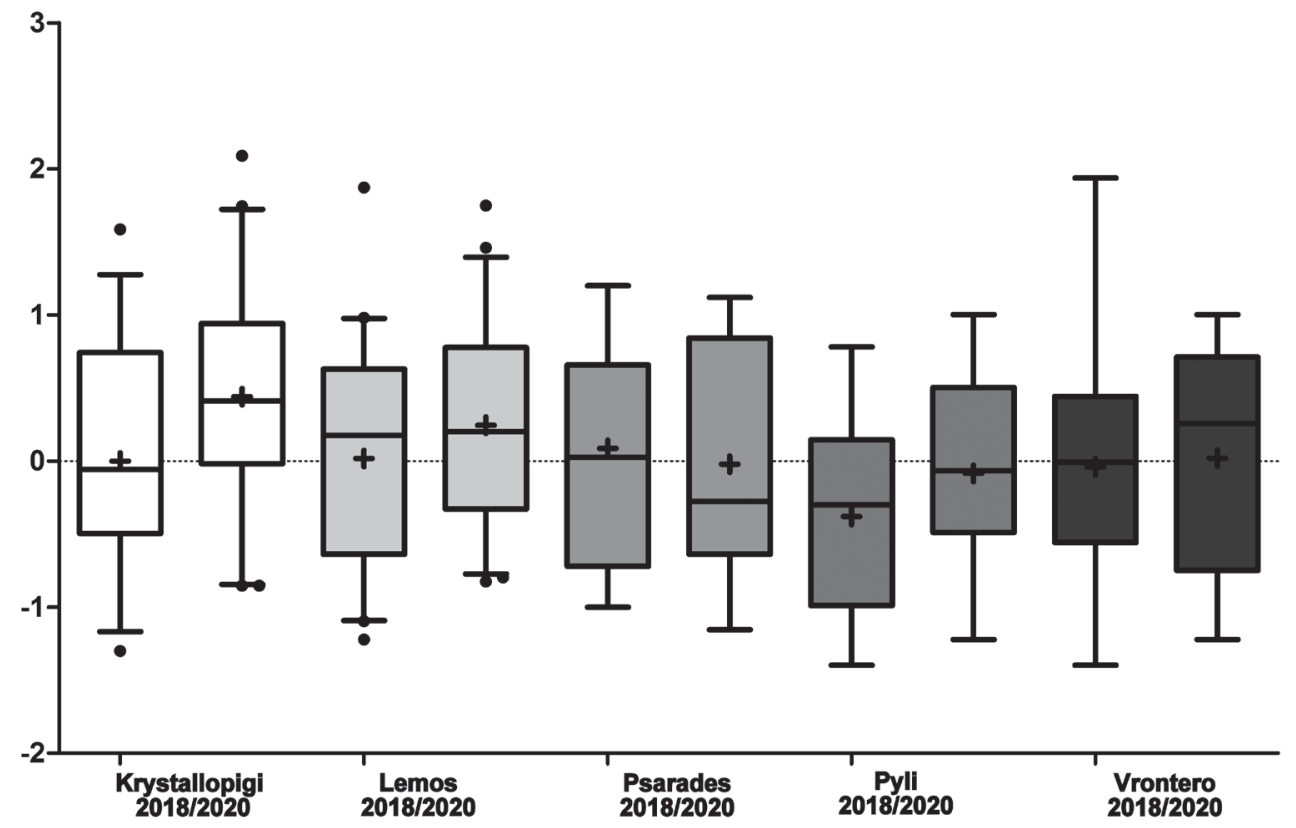

Fig. 4. Patterns of the light pollution as revealed from the survey in five priority villages in the Prespa basin in the 2018 and 2020 seasons. Whiskers: 5-95 percentile, '+' = mean. Because of a great dispersal, the illumination values were log transformed (for the exact data see Table 6).

Obr. 4. Obraz svetelného znečistenia vyplývajúci z prieskumu v piatich prioritných obciach Prespanskej kotliny v rokoch 2018 a 2020. Línie: 5-95 percentily, '+' = priemer. V dôsledku vel'kého rozptylu boli hodnoty osvetlenia logaritmicky transformované. 


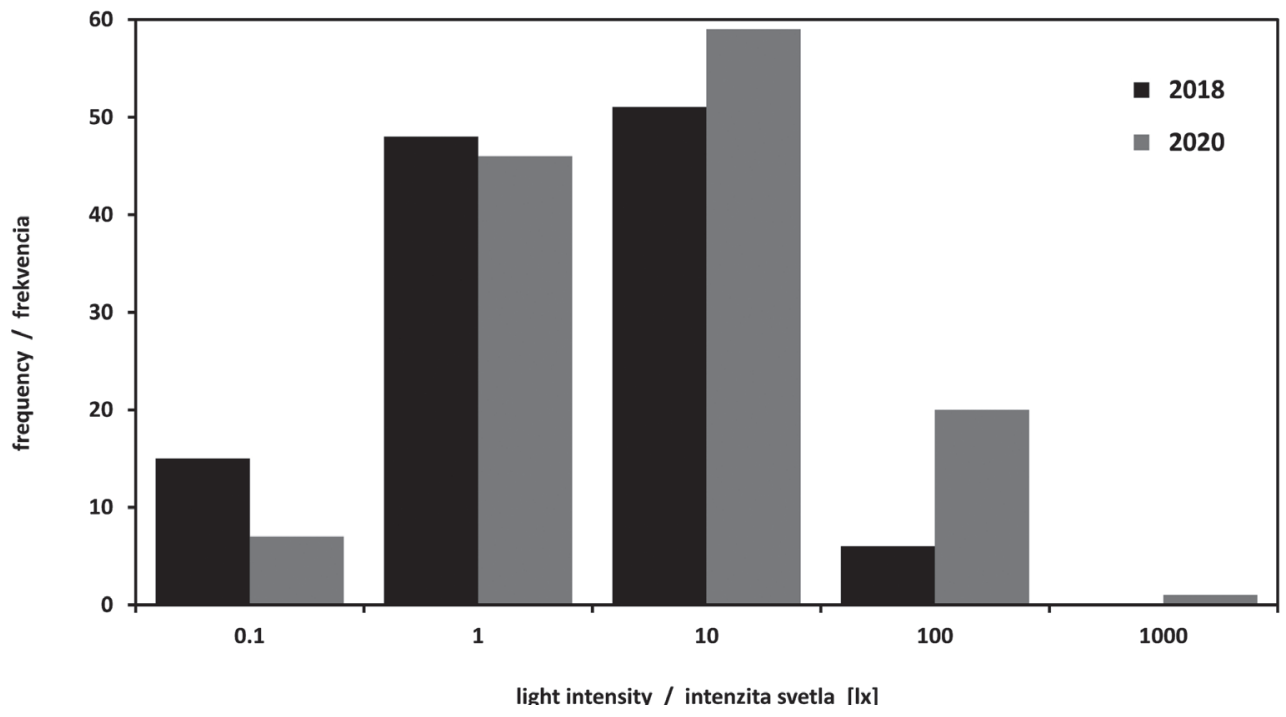

Fig. 5. Frequency histograms of light illumination intensity in selected ranges in the 2018 and 2020 surveys. Obr. 5. Histogramy frekvencií intenzity osvetlenia vo vybraných rozsahoch v prieskumoch v rokoch 2018 a 2020.

Explanation / vysvetlenie: $x$ axis - luxmeter value ranges / os $x$ - rozsahy merania luxmetra: $\mathbf{0 . 1}=$ $0.01-0.1 \mathrm{~lx}, \mathbf{1}=0.11-1 \mathrm{~lx}, \mathbf{1 0}=1.1-10 \mathrm{~lx}, \mathbf{1 0 0}=10.1-100 \mathrm{~lx}, \mathbf{1 0 0 0}=100.1-1000 \mathrm{~lx}$.

the village in the parts with low light pollution. During the second year we recorded the highest bat activity in the southeastern part of the village. It is worth of mention, that bats were active not only in the peripheral zone with the highest illumination intensity, but also directly inside of this area. In this part, we recorded presence of the lamps with a special construction which prevented light from escaping towards the sky and, conversely, light with high intensity was directed downwards and to the sides (Fig. 6D). The other group of bat positions was recorded

Fig. 6. Examples of night artificial lights in the Prespa region. A - line of street lights (Lemos). B - light with higher light intensity (Pyli). C - dysfunctional ball lights (Lemos). D - lamp with "bat friendly" construction (Krystallopigi). $\mathbf{E}$ - a pair of ball lamps, one is off (Pyli). $\mathbf{F}$ - a pair of ball lamps with white and yellow light (Pyli). $\mathbf{G}$ - comparison of a higher lamp without cover with a lower ball lamp with white light (Krystallopigi). H - tall lamp without cover with yellow light (Psarades). I - lamp of another shape with yellow light (Lemos). Photo by Marcel Uhrin, Romana Uhrinová \& Viktória VARgová.

Obr. 6. Príklady nočného osvetlenia v Prespanskej kotline. A - línia uličných lámp (Lemos). B - svetlo s vyššou svetelnou intenzitou (Pyli). C - nefunkčné kruhové svetlo (Lemos). D - lampa s "bat friendly" konštrukciou (Krystallopigi). E-dvojica kruhových lámp, jedna nefunkčná (Pyli). F-dvojica kruhových lámp, jedna s bielym, jedna so žltým svetlom (Pyli). G - porovnanie vyššej lampy bez krytu s nižšou s bielym svetlom (Krystallopigi). H - vysoká lampa bez krytu so žltým svetlom (Psarades). I - lampa iného tvaru so žltým svetlom (Lemos). Fotografie Marcel Uhrin, Romana UhrinovÁ \& Viktória VArGOVÁ. 

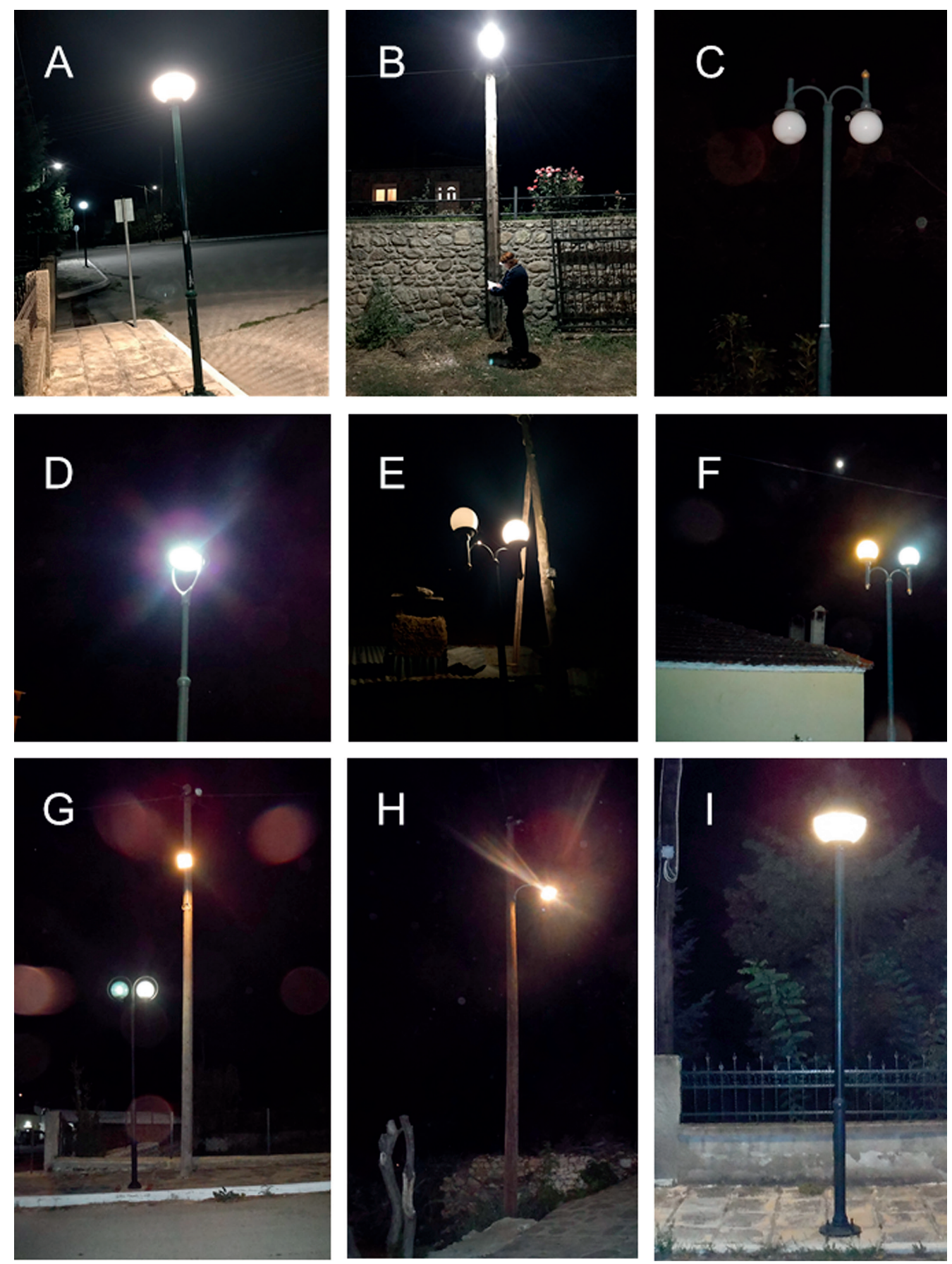

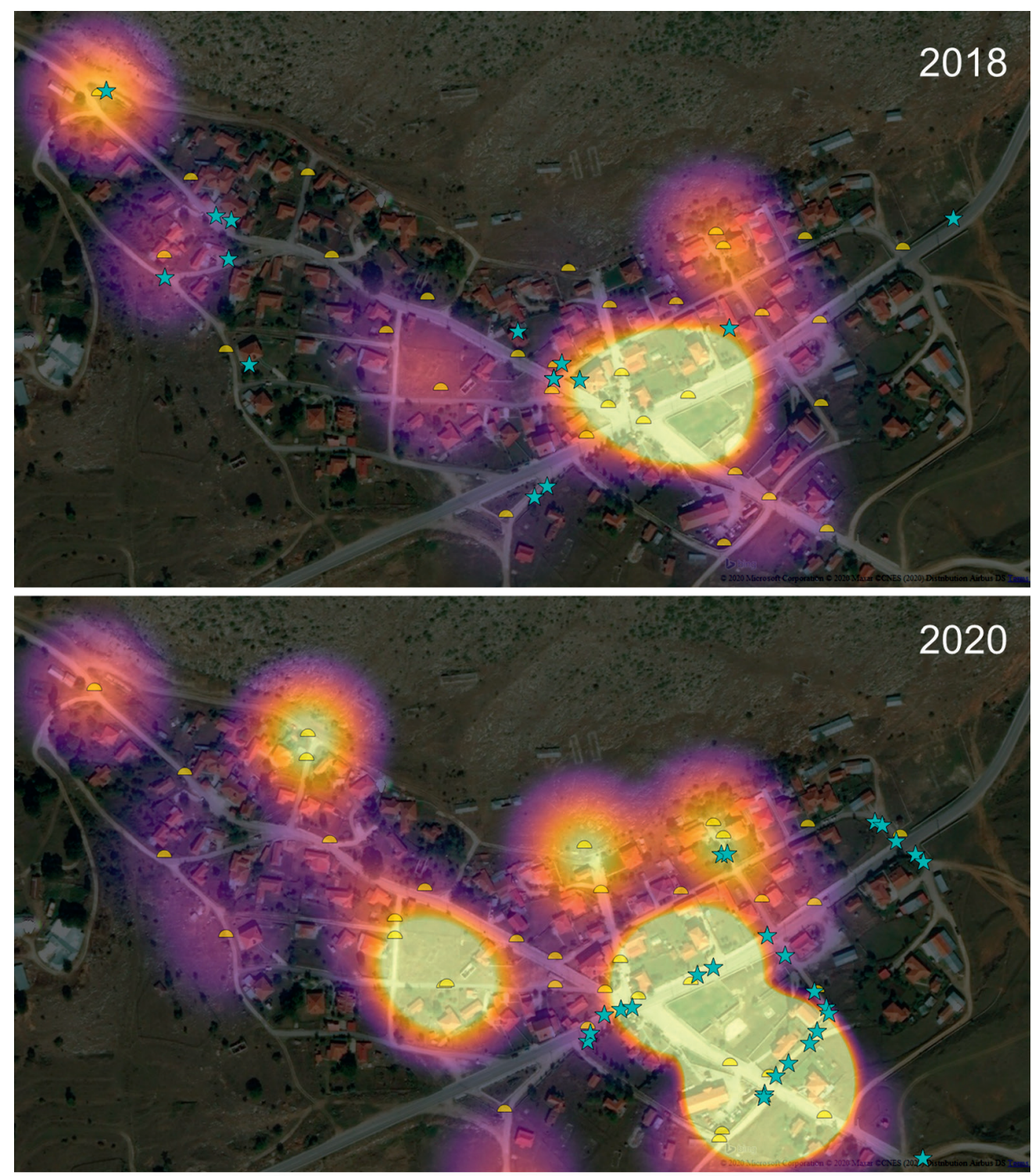

Fig. 7. Light pollution distribution map in the priority villages of the Prespa basin in 2018 and 2020: Krystallopigi. Heatmap of illumination intensity is based on data from measuring points (yellow semicircle), asterisks represent bat records (for illumination data and for bat records see Tables 4-6).

Obr. 7. Distribúcia svetelného znečistenia v prioritných obciach Prespanskej kotliny v roku 2018 a 2020: Krystallopigi. Tepelná mapa intensity osvetlenia je založená na meracích bodoch (žlté polkruhy), hviezdičky reprezentujú záznamy netopierov (údaje o osvetlení a aktivite netopierov sú uvedené v tab. 4-6). 
similarly as in the previous season, on the outskirts of the village near lamps with low light pollution. During the first monitoring year in Lemos, we recorded low light intensity and bat activity in general. Bats were more concentrated in the central part of the village in parts with
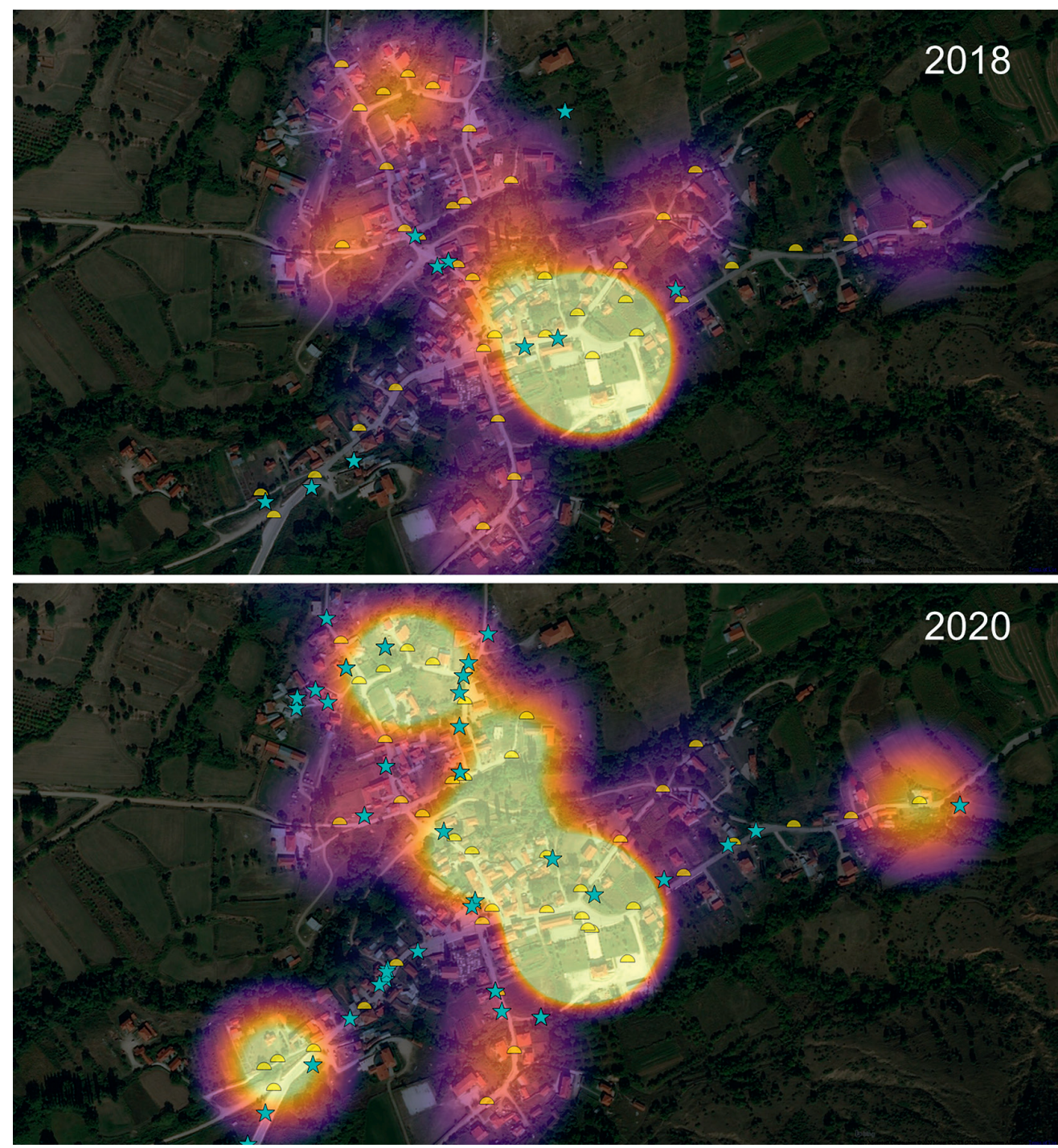

Fig. 8. Light pollution distribution map in the priority villages of the Prespa basin in 2018 and 2020: Lemos. For explanations see Fig. 7.

Obr. 8. Distribúcia svetelného znečistenia v prioritných obciach Prespanskej kotliny v roku 2018 a 2020: Lemos. Pre vysvetlivky pozri obr. 7. 

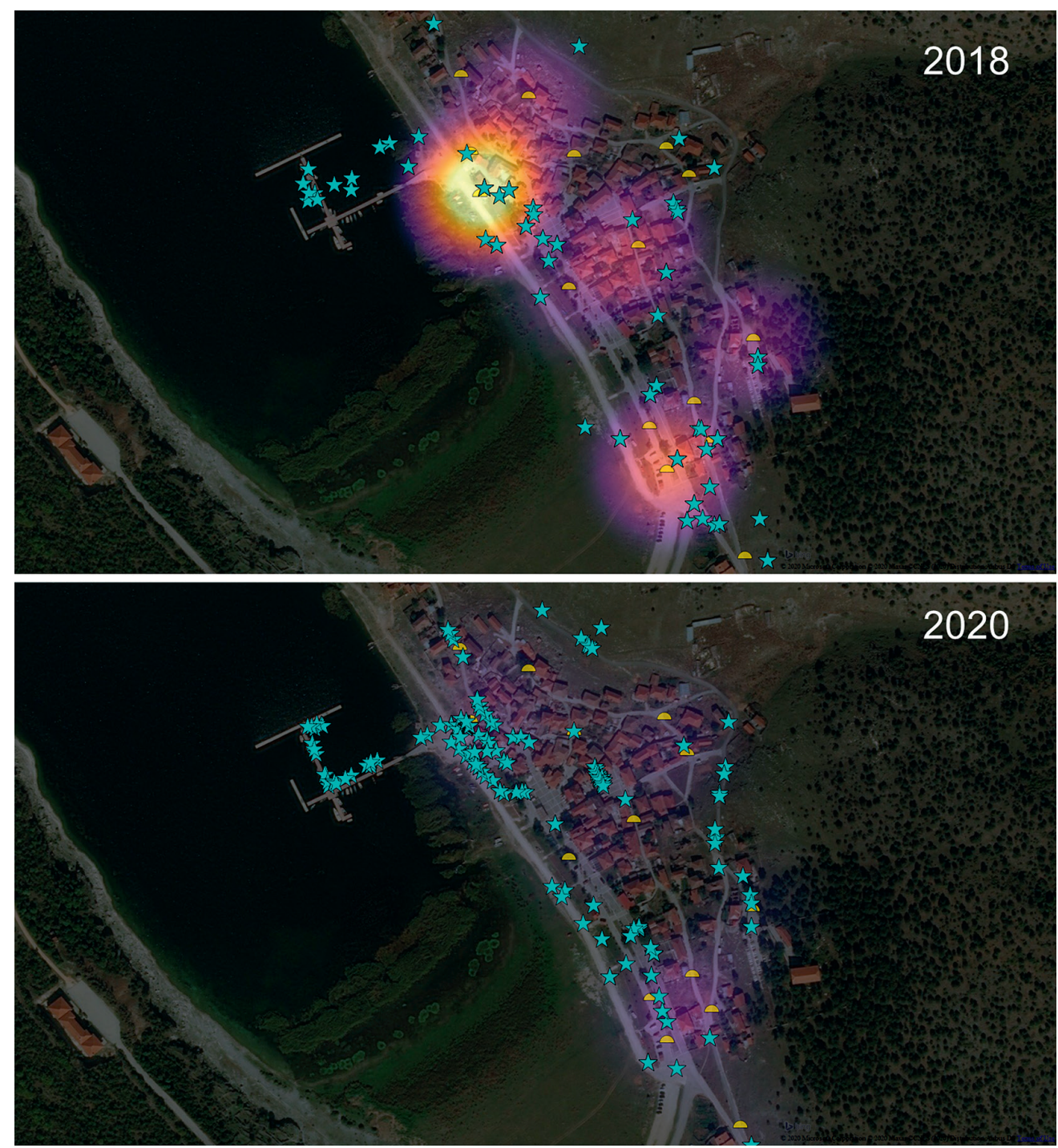

Fig. 9. Light pollution distribution map in the priority villages of the Prespa basin in 2018 and 2020: Psarades. For explanations see Fig. 7.

Obr. 9. Distribúcia svetelného znečistenia v prioritných obciach Prespanskej kotliny v roku 2018 a 2020: Psarades. Pre vysvetlivky pozri obr. 7.

low light intensity than in the zone with the highest light intensity (Fig. 8). Some bats were also recorded on the outskirts of the village where the lighting was very low. However, during the second year we recorded considerable differences in the light intensity and also in the bat 
activity in this village, in both cases there was a significant increase. The illumination was most pronounced in the central and northern parts of the village and descended towards the peripheries. The bat activity was recorded mostly in the peripheral parts of this highest lighting
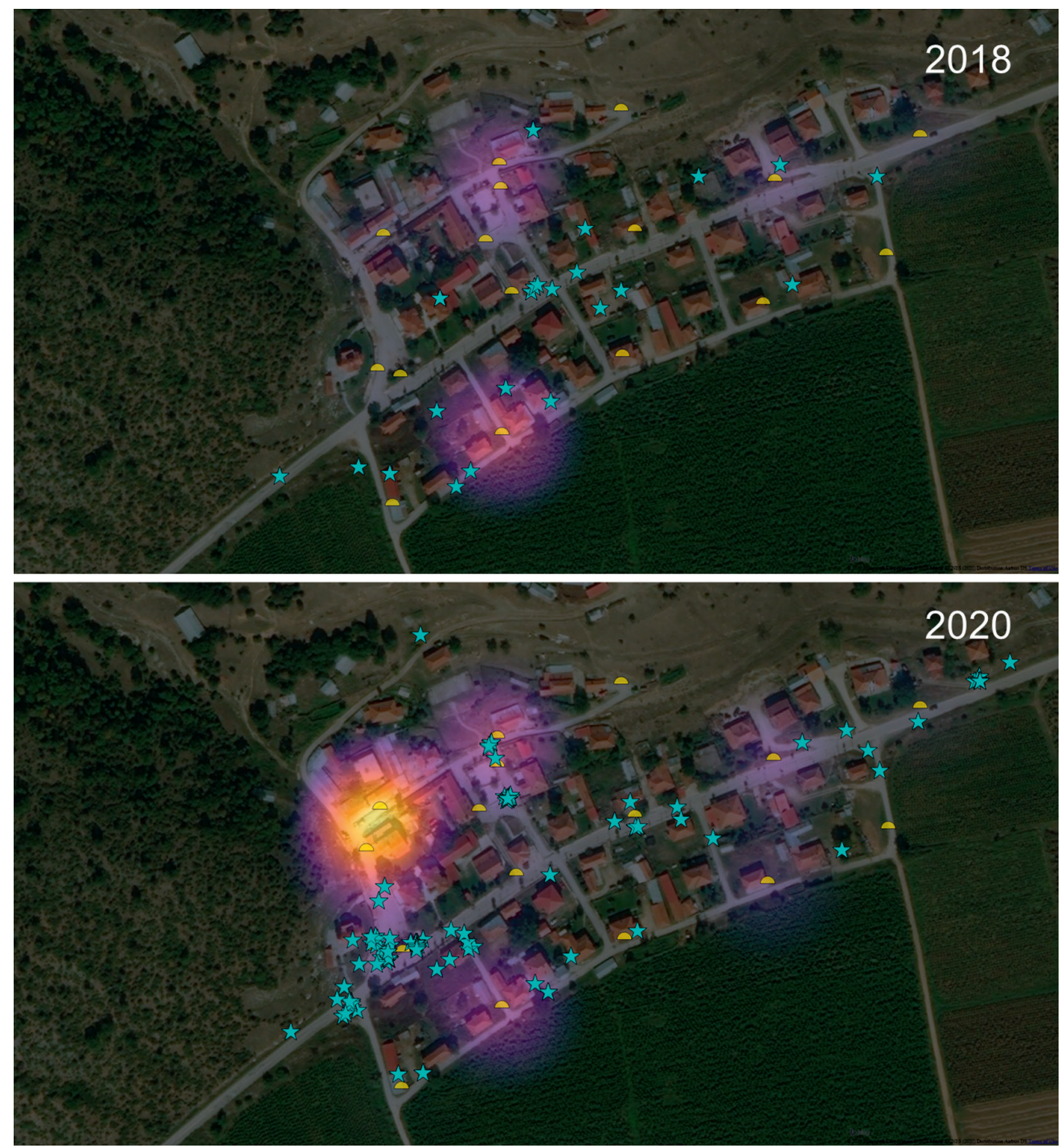

Fig. 10. Light pollution distribution map in the priority villages of the Prespa basin in 2018 and 2020: Pyli. For explanations see Fig. 7.

Obr. 10. Distribúcia svetelného znečistenia v prioritných obciach Prespanskej kotliny v roku 2018 a 2020: Pyli. Pre vysvetlivky pozri obr. 7. 
zone where intensity gradually decreased. Bats were also present near lamps in the marginal parts of the village.

In Psarades, we observed a significantly higher bat activity also during the second measurement period. Overall, the village looked less lit this time than during the first season in 2018. Also, the lower street with restaurants near the port made a darker impression and was without the presence of people (perhaps a consequence of the Covid 19 pandemic). This street and the port were the places of the highest activity of bats during the second visit. During the first year of the survey, we also detected the highest bat aggregations there, but they were not so numerous compared to the second measurement period. In the upper streets of the village, bats were also more concentrated during the second visit than for the first time (Fig. 9).

Pyli was the village with the lowest values of illumination intensity during both survey periods. However, in the second year we recorded an almost twice higher illumination intensity and even higher bat activity (Fig. 10) than in the first year. Bats were mostly concentrated in the western part of the village where the church is located and we did not record high light intensity in this part. The activity of bats was further dispersed through the whole village, but the bats almost clearly avoided the northwestern part of the village with the highest lighting. During the second year we did not record a similar acitivity of bats near the church as in the previous year. The animals were active mostly in the central part of the village that time.

During the first year, Vrontero had a strong lighting source (halogen lamp) in its western part which is well visible in the heatmap (Fig. 11). Bats avoided the central part of this area, but they were very numerous in its peripheral zone. The other significant bat activity was recorded at the southwestern edge of the village which represented the most numerous aggregations during the second survey. The largest part of the village during the first year had a lower light intensity and the activity of bats was dispersed there. In the second year, the dispersed bat activity pattern through the village was significantly lower than the previous time. On the other hand, we measured a high light pollution in the whole village except for the part with halogen lamps because some of them were switched off. Comparing heat maps between the two seasons, the negative relationship between illumination intensity and bat activity can be observed.

It is important to stress that the bat activity is also influenced by various factors such as the air temperature and other weather conditions (e.g., wind, air humidity or fog presence). These conditions may have affected the intensity of bat activity in the villages, but from the presented heatmaps we can see the character of bat distribution in their different parts.

\section{CONCLUSIONS AND RECOMMENDATIONS}

The survey in 2018-2020 confirmed, despite the limited methods used, the extraordinary importance of the Greek part of the Prespa region for bat diversity. The study documented the presence of 22 bat forms ( 20 species) through acoustic surveys, the favourable status of some previously known roosts, while nursery colonies of several species were newly recorded. Additionally, three of the recorded species are here reported from the region for the first time, namely the northern bat (Eptesicus nilssonii) - the first record also for Greece, the greater noctule bat (Nyctalus lasiopterus) and the western barbastelle (Barbastella barbastellus), yet these findings require confirmation by capture or direct observation of an individual. According to the collected data, bats do not avoid the urbanized parts of the study area, which are represented by the focus (and other) villages (Krystallopigi, Lemos, Psarades, Pyli, Vrontero), a finding that underlines the importance of old houses, churches, and ruins that still provide suitable roost and prey opportunities, despite the fact that light conditions inside the villages are not nature-friendly. 

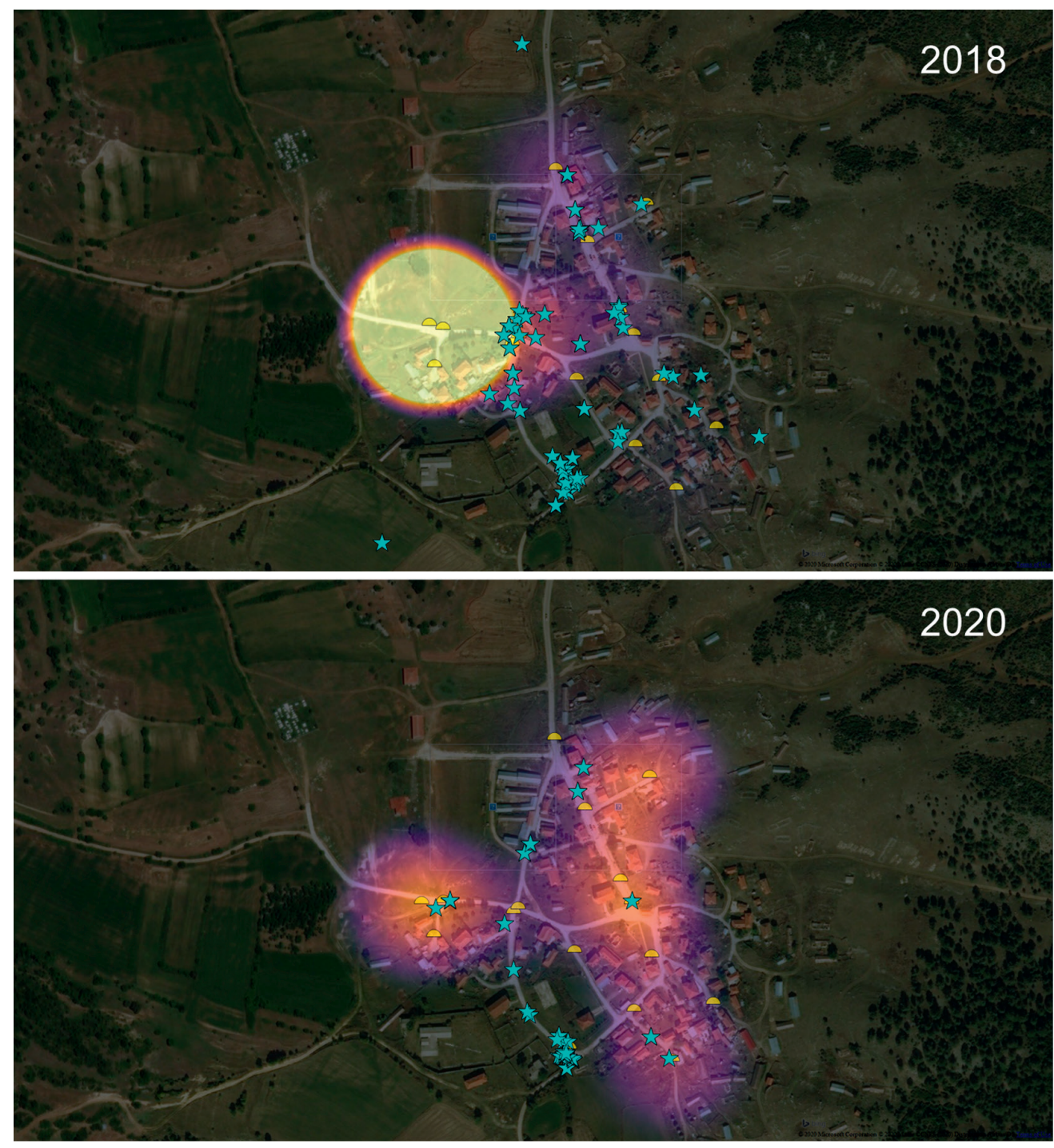

Fig. 11. Light pollution distribution map in the priority villages of the Prespa region in 2018 and 2020: Vrontero. For explanations see Fig. 7.

Obr. 11. Distribúcia svetelného znečistenia v prioritných obciach Prespanskej kotliny v roku 2018 a 2020 : Vrontero. Pre vysvetlivky pozri obr. 7.

The existing lights did not conform with most of recommendations to be ecologically acceptable. The aim of the street light lamps' replacement should be to eliminate light pollution and its negative impacts on organisms and ecosystems. Prior to the authors' second visit in late 
September - early October 2020, an effort to replace street light lamps had been made by the Municipality of Prespa but it had not been completed by the time of the visit. More specifically, only street light lamps on the wooden public electricity poles were replaced, while the municipal street light lamps, which form the majority of night lights in the focus villages, had still not been replaced in October 2020. The changes made until that time (Fig. 6H) did not have any notable effect on bat activity, as documented by the second field-work session, and therefore the remaining replacements should be accomplished as soon as possible.

The measurements of light pollution in all focus villages revealed a high amount of light diffusion caused by the type of shield-less luminaires, they thus contribute to the light emissions (skyglow) significantly. In some cases, such lines of lights of this type could act as a barrier for both bats and their prey (moths). The documentation of occurrence of "dark zones" with lower values of illumination in Psarades and Vrontero during the second field-work period was a positive change, yet it is not clear whether this change is intended and thus will be permanent or it should just be attributed to broken lamps that were not replaced. Luminaires that prevent light diffusion towards the sky, and thus conform to the relevant recommendations, were documented in a few parts of some villages, however, these were only the exceptions and not the rule.

Heat maps of light intensity and bat activity drawn for all villages for 2018 and 2020 revealed a slightly higher bat activity in almost all villages in 2020. Bat passes were, in general, recorded not only in the peripheral zones of the highest illumination zones of the villages, but also inside them although some of the bat passes may belong to bats flying enough in the dark above the light levels of the installed lamps. This higher bat activity was recorded in all focus villages, and whereas the overall lower light pollution recorded in some villages (Psarades, Vrontero) could be an explanatory factor, there are certainly other associated factors, such as the air temperature, wind or also the weather-related prey activity, etc. For example, both the relatively strong wind during and after the dusk on the Vrontero karstic plateau and nightly heat radiating stony slopes above the Pyli village could significantly (positively or negatively) influenced the bat activity, especially as observed in the 2020 season. On the other hand, the artificial lights also attract nocturnal insects (which are bat prey) and especially when they are light interconnected, could play as night traps and simultaneously cause insect exhaustion in the dark zones. Thus, the strength of impacts of all these factors upon the bat activity level could be accurately evaluated with the emphasis toward light pollution only after the application of nature-friendly mitigation actions (see below) in practice.

The Municipality of Prespa had proposed to replace the existing lamps with the LED bulbs. Following the EUROBATS guidelines, based on the data gathered and taking into account that the region is situated in the center of a protected area (national park), the main aim should be to reduce the current level of the ALAN (Artificial Light At Night) in general; such approach will help improve ecological conditions not only for the bat community; this general aim can be achieved by application of the following mitigation actions:

- to minimize light diffusion and contribution to skyglow, existing luminaires should be replaced with other lighting only in downwards direction;

- to reduce, if possible, the number of lights used in all villages and to leave adequate zones of "darkness";

- where possible, to use low pylons for the lights with the aim to concentrate lighting only on the street surface and to avoid light passing to the surrounding habitats;

- only the long-wavelength lamps should be used and the currently installed lamps should be replaced with lamps emitting "cold-white" light below $540 \mathrm{~nm}$ and with colour temperature $>2,700 \mathrm{~K}$. 


\section{SÚHRN}

Prieskum netopierov gréckej časti Prespanskej kotliny v rokoch 2018-2020 potvrdil napriek limitom použitých metód jej mimoriadny význam $\mathrm{z}$ hl’adiska ich diverzity. V štúdii sa prevažne na základe akustického prieskumu dokumentuje prezencia 22 foriem ( 20 druhov) netopierov a potvrdzuje priaznivý stav niektorých už v minulosti známych úkrytov, vrátane niekol'kých reprodukčných kolónií. Prvýkrát sa v oblasti zaznamenali tri druhy netopierov, večernica severská Eptesicus nilssonii (prvý záznam pre Grécko), raniak obrovský Nyctalus lasiopterus a uchaňa čierna Barbastella barbastellus, výskyt týchto druhov si však vyžaduje potvrdenie odchytom alebo priamym pozorovaním. Získané údaje potvrdili, že netopiere sa urbanizovaným častiam skúmanej oblasti nevyhýbajú, čo zvýrazňuje význam starých a opustených domov, kostolov a ruín, poskytujúcich vhodné úkryty ako aj zdroj potravy. Meranie svetelného znečistenia v prioritných obciach oblasti odhalilo vysokých podiel difúzie svetla v závislosti na type pouličných svietidiel. Tepelné mapy svetelných intenzít ukázali v roku 2020 mierne vyššiu aktivitu netopierov v takmer všetkých obciach. Prelety netopierov boli zaznamenané nielen v okrajových častiach najviac osvetlených zón, ale aj v ich vnútri, aj ked' niektoré z preletov môžu patrit' netopierom lietajúcim v tmavej zóne nad úrovňou svetla inštalovaných lámp. Štúdia navrhuje mitigačné opatrenia pre samosprávu Prespanskej oblasti s ciel'om znížit' aktuálnu hladinu umelého nočného osvetlenia (ALAN - Artificial Light At Night).

\section{Acknow ledgments}

We thank Stanislav Danko, Gréta Nusová, and Janka Uhrinová for their help in the field. We are also indebted to Thanos Kastritis and Olga Alexandrou from the Society for the Protection of Prespa for their extremely useful assistance with the organization of field trips. The study was conducted within the project "Integration of Photovoltaic Plants for self-consumption under the Net Metering Concept in Public Buildings/Pumping Stations and Replacement of Low-Efficiency Municipal/Street Lighting with LED Lights" co-funded by the European Union and National Funds of the participating countries under the framework of the Interreg IPA CBC Programme "Greece - Albania 2014-2020" and partly by the project from Scientific Grant Agency VEGA (\# 1/0298/19).

\section{REFERENCES}

Acharya L. \& Fenton M. B., 1999: Bat attacks and moth defensive behaviour around street lights. $\mathrm{Ca}$ nadian Journal of Zoology, 77: 27-33.

Arlettaz R., Godat S. \& Meyer H., 2000: Competition for food by expanding pipistrelle bat populations (Pipistrellus pipistrellus) might contribute to the decline of lesser horseshoe bats (Rhinolophus hipposideros). Biological Conservation, 93: 55-60.

Aubé M., 2015: Physical behaviour of anthropogenic light propagation into the nocturnal environment. Philosophical Transactions of the Royal Society B: Biological Sciences, 370(1667: 20140117): 1-15.

Azam C., Le Viol I., Bas Y., Zissis G., Vernet A., Julien J.-F. \& Kerbiriou C., 2018: Evidence for distance and illuminance thresholds in the effects of artificial lighting on bat activity. Landscape and Urban Planning, 175: 123-135.

BARATAUd M., 2015: Acoustic Ecology for European Bats. Species Identification, Study of Their Habitats and Foraging Behaviour. Inventaires et Biodiversité Series. Biotope \& Muséum national d'Histoire naturelle, Mèze \& Paris, 352 pp.

Benda P., Ševčík M., Bego F., Sachanowicz K., Spitzenberger F., Tájek P., Tájková P. \& Uhrin M., 2019: Bats (Mammalia: Chiroptera) of the Eastern Mediterranean and Middle East. Part 15. The fauna of bats and bat ectoparasites of Albania with a catalogue of bats from the western Balkans in the collection of the National Museum, Prague. Acta Societatis Zoologicae Bohemicae, 83: 1-238.

Bennie J., Davies T. W., Cruse D., Inger R. \& Gaston K. J., 2015: Cascading effects of artificial light at night: resource-mediated control of herbivores in a grassland ecosystem. Philosophical Transactions of the Royal Society B: Biological Sciences, 370(1667: 20140131): 1-9. 
Boldogh S., Dobrosi D. \& SAmu P., 2007: The effects of the illumination of buildings on house-dwelling bats and its conservation consequences. Acta Chiropterologica, 9: 527-534.

Bousbouras D. \& IoAnNidis Y., 1994: Amphibien und Reptilien des Prespa-Nationalparks und der Gebirgeregion um Florina (Mazedonien, Griechenland). Salamandra, 30: 209-220.

Brajanoska R., Henderson J., Kastritis T., Malakou M., Roumeliotou V. \& Shumka S. (eds.), 2017: Transboundary Prespa - Review of Conservation Efforts. A Report to the Prespa Ohrid Nature Trust. Society for the Protection of Prespa, Macedonian Ecological Society \& Protection and Preservation of the Natural Environment Albania (PrespaNet), Agios Germanos, 158 pp.

Catsadorakis G., 1995: The Texts of the Information Centre of Prespa. Society for the Protection of Prespa, Agios Germanos, 126 pp.

Catsadorakis G, 1999: Prespa. A Story for Man and Nature. Society for the Protection of Prespa, Agios Germanos, xxiv $+180 \mathrm{pp}$.

Catsadorakis G., 2002: The Book of Pelicans. Agios Germanos, Agios Germanos, 181 pp.

Catsadorakis G. \& Kollaros D., 1986: Preliminary notes on the mammalian fauna of Lake Prespa National Park (Greece). Biologia Gallo-Hellenica, 12: 507-519.

Celuch M., Uhrin M., BAČKOR P. \& ŠEvČíK M., 2016: Monitoring netopierov pomocou autotransektov prvé výsledky zo Slovenska [Car-based bat monitoring - first results from Slovakia]. Vespertilio, 18: 41-54 (in Slovak, with an abstract in English).

Crivelli A. J. \& Catsadorakis G. (eds.), 1997: Lake Prespa, Northwestern Greece. A Unique Balkan Wetland. Hydrobiologia, 351: 1-196.

Davies T. W., Bennie J. \& Gaston K. J., 2012: Street lighting changes the composition of invertebrate communities. Biology Letters, 8: 764-767.

Davies T. W., Bennie J., Inger R. \& Gaston K. J., 2013: Artificial light alters natural regimes of night-time sky brightness. Scientific Reports, 3: 1722.

Davies T. W., Coleman M., Griffith K. M. \& Jenkins S. R., 2015: Night-time lighting alters the composition of marine epifaunal communities. Biology Letters, 11(4: 20150080): 1-5.

Dominoni D. M., Borniger J. C. \& Nelson R. J., 2016: Light at night, clocks and health: from humans to wild organisms. Biology Letters, 12(2: 20160015): 1-4.

EISENBEIS G., 2006: Artificial night lighting and insects: attraction of insects to streetlamps in a rural setting in Germany. Pp.: 191-198. In: Rich C. \& LongCore T. (eds.): Ecological Consequences of Artificial Night Lighting 2. Island Press \& Covelo, Washington \& London, 480 pp.

Galand N., Declerce S., Cheyrezy T., Puechmaille S. J., Deguines N., Grémillet X., Papadatou E. \& KazOGLOU Y., 2010: Bat survey on the subalpine grasslands of Mt Varnous (Florina, Greece): preliminary results. Pp.: 305-314. In: Sidiropoúlou Á., MANTZANÁs K. \& IspiKoúdis I. (eds.): Livadoponia kai poiotita zois. Praktiká 7ou Panellíniou Livadoponikoú Synedriou Xánthi, 14-16 Oktovríou 2010. Range Science and Life Quality. Proceedings of the 7th Panhellenic Rangeland Congress in Xanthi, 14-16 October 2010. Ministry of Environment, Energy and Climate Change, Derectorate General for the Development and Protection of Forests and Natural Environment \& Hellenic Pasture and Range Society, Thessaloniki, 329 pp.

Gaston K. J., Duffy J. P., Gaston S., Bennie J. \& Davies T. W., 2014: Human alteration of natural light cycles: causes and ecological consequences. Oecologia, 176: 917-931.

Gaston K. J., Visser M. E. \& HöLKer F., 2015: The biological impacts of artificial light at night: the research challenge. Philosophical Transactions of the Royal Society B: Biological Sciences, 370(1667: 20140133): 1-6.

Gremillet X. \& Boireau J., 2004: Les chauves-souris du Parc National de Prespa. Macédoine occidentale-Grèce. Rapport interne. Groupe Mammalogique Breton, Sizun, 35 pp.

Grémillet X. \& Dubos T. 2008: Bilan chiroptérologique des prospections estivales organisées par le Groupe Mammalogique Breton dans le Parc National de Prespa-Macédoine occidentale, Grèce. Mimeographed report. Groupe Mammalogique Breton, Sizun, 48 pp.

Gremillet X., Dubos T. \& Le Champion T., 2010: Bilan chiroptérologique des prospections estivales organisées jusqu'en 2007 par le Groupe Mammalogique Breton dans le Parc National de Prespa, Macédoine occidentale (Grèce). Symbioses, 25: 1-6. 
Haffner M. \& Stutz H. P., 1985: Abundance of Pipistrellus pipistrellus and Pipistrellus kuhlii foraging at street-lamps. Myotis, 23-24: 167-172.

Hammer Ø., HaRPer D. A. T. \& Ryan P. D., 2001: PAST: Paleontological statistics software package for education and data analysis. Palaeontologia Electronica, 4(1): 1-9.

HANÁK V. \& HorÁČEK I., 1986: Zur Südgrenze des Areals von Eptesicus nilssoni (Chiroptera: Vespertilionidae). Annalen des Naturhistorischen Museums in Wien, 88-89B: 377-388.

HanÁk V., Benda P., Ruedi M., Horáček I. \& Sofianidou T. S., 2001: Bats (Mammalia: Chiroptera) of the Eastern Mediterranean. Part 2. New records and review of distribution of bats in Greece. Acta Societatis Zoologicae Bohemicae, 65: 279-346.

von Helversen O. \& Weid R., 1990: Die Verbreitung einiger Fledermausarten in Griechenland. Bonner Zoologische Beiträge, 41: 9-22.

HölKer F., Wolter C., Perkin E. K. \& Tockner K., 2010: Light pollution as a biodiversity threat. Trends in Ecology \& Evolution, 25: 681-682.

van Langevelde F., Braamburg-Annegarn M., Huigens M. E., Groendijk R., Poitevin O., van Deijk J. R., Ellis W. N., van Grunsven R. H. A., De Vos R. \& Vos R. A., 2018: Declines in moth populations stress the need for conserving dark nights. Global Change Biology, 24: 925-932.

LewanziK D. \& Voigt C. C., 2017: Transition from conventional to light-emitting diode street lighting changes activity of urban bats. Journal of Applied Ecology, 54: 264-271.

Longcore T., Aldern H. L., Eggers J. F., Flores S., Franco L., Hirshfield-Yamanishi E., Petrinec L. N., YAN W. A. \& BArroso A. M., 2015: Tuning the white light spectrum of light emitting diode lamps to reduce attraction of nocturnal arthropods. Philosophical Transactions of the Royal Society B: Biological Sciences, 370(1667: 20140125): 1-10.

Micevski N., Presetnik P., Micevski B. \& Celuch M., 2014: Contribution to knowledge about Macedonian bat fauna. Vespertilio, 17: 103-114.

Middleton N., Froud A. \& French K., 2014: Social Calls of the Bats of Britain and Ireland. Pelagic Publishing, Exeter, xi+176 pp.

Mohar A., Zagmajster M., Verovnik R. \& Bolta Skaberne B., 2014: Nature-friendlier Lighting of Objects of Cultural Heritage (Churches) - Recommendations. Dark-Sky Slovenia, Ljubljana, 28 pp.

Obrist M. K., Boesch R. \& FlÜCKIGER P. F., 2004: Variability in echolocation call design of 26 Swiss bat species: consequences, limits and options for automated field identification with a synergetic pattern recognition approach. Mammalia, 68: 307-322.

Papadatou E., Butlin R. K. \& Altringham J. D., 2008: Identification of bat species in Greece from their echolocation calls. Acta Chiropterologica, 10: 127-143.

Papadatou E., Grémillet X. \& Kazoglou Y., 2010: Desing and Organization of a Transboundary Monitoring System (TMS) for the Prespa Park. Pilot Application of the Transboundary Monitoring System for the Prespa Park: Workshop on the Monitoring of Bats (Stenje, Galicica National Park, 26-28 July 2010). Final Report. Society for the Protection of Prespa, Agios Germanos, 25 pp.

Papadatou E., Grémillet X., Bego F., Petkovski S., Stojkoska E., Avramoski O. \& Kazoglou Y., 2011 : Status Survey and Conservation Action Plan for the Bats of Prespa. Society of the Protection of Prespa, Prespa \& Ag. Germanos, 191 pp.

Papadatou E., Gichevski B., Stojanov A., Avukatov V., Brajanoska M. S., Melovski L. \& Hristovski S., 2012: Status Survey and Conservation Action Plan for the Caves and Cave Bats of Prespa. Project "Landscape Scale Conservation in the Prespa Lake Basin - Transboundary Species and Habitat Conservation Action Plans". Final Report. Unpubl. report. 54 pp.

Papadatou E., Puechmaille S., Grémillet X., Georgiakis P., Galand N., Deguines N., Declerce S., CheYrezy T. \& Kazoglou Y., 2013: Bat diversity and activity at subalpine grasslands of Varnous and Triklarion Mountains (NW Greece). Pp.: 233-238. In: VrahnaKis M., Kyriazopoulos A. P., Chouvardas D. \& Fotiadis G. (eds.): Dry Grasslands of Europe: Grazing and Ecosystem Services. Proceedings of 9th Dry Grassland Meeting (EDGM). Prespa, Greece, 12-23 May 2012. Hellenic Range and Pasture Society (HERPAS), Thessaloniki, $352 \mathrm{pp}$. 
Patriarca E. \& Debernardi P., 2010: Bats and Light Pollution. Centro Regionale Chirotteri, Ente di Gestione del Parco Naturale Laghi di Avigliana, Avigliana, 27 pp.

Paunovic M., Pandurska R., Ivanova T. \& Karapand[ž]a B., 2003: Present knowledge of distribution and status of Barbastella barbastellus (Schreber, 1774) (Chiroptera: Vespertilionidae) on the Balkan peninsula. Nyctalus (N. F.), 8(6): 633-638.

Paumels J., Le Viol I., Azam C., Valet N., Julien J. F., Bas Y., Lemarchand C., Sanchez De Miguel A. \& KerBIRIOU C., 2019: Accounting for artificial light impact on bat activity for a biodiversity-friendly urban planning. Landscape and Urban Planning, 183: 12-25.

Pavlinić I. \& TVRTKović N., 2003: The presence of Eptesicus nilssonii and Vespertilio murinus in the Croatian bat fauna confirmed. Natura Croatica, 12: 55-62.

Perennou C., Gletsos M., Chauvelon P., Crivelli A., DeCoursey M., Dokulil M., Grillas P., Grovel R. \& SAndoz A., 2009: Development of a Transboundary Monitoring System for the Prespa Park Area. Expert Study. Society for the Protection of Prespa, Aghios Germanos, 381 pp.

PRESETNIK P., 2015: Contribution to spring Chiroptera fauna of lake Great Prespa and its vicinity in the Republic of Macedonia. Buletini i Shkencave Natyrore, 20: 45-54.

Rich C. \& LongCore T. (eds.), 2006: Ecological Consequences of Artificial Night Lighting. Island Press $\&$ Covelo, Washington \& London, $480 \mathrm{pp}$.

Rowse E. G., Lewanzik D., Stone E. L., Harris S. \& Jones G., 2016: Dark matters: the effects of artificial lighting on bats. Pp.: 187-213. In: Voigt C. C. \& Kingston T. (eds.): Bats in the Anthropocene: Conservation of Bats in a Changing World. Springer, Cham, ix $+606 \mathrm{pp}$.

Rydell J., 1992: Exploitation of insects around streetlamps by bats in Sweden. Functional Ecology, 6: 744-750.

Rydell J., EklöF J. \& SÁnchez-Navarro S., 2017: Age of enlightenment: long-term effects of outdoor aesthetic lights on bats in churches. Royal Society Open Science, 4(8: 161077): 1-8.

Sanders D., Frago E., Kehoe R., Patterson C. \& Gaston K. J., 2020: A meta-analysis of biological impacts of artificial light at night. Nature Ecology \& Evolution, 5: 74-81.

Scheffler I., Bego F., Théou P., Podany M., Pospischil R. \& Hübner S., 2013: Ektoparasiten der Fledermäuse in Albanien - Artenspektrum und Wirtsbindung. Nyctalus (N. F.), 18(1): 84-109.

Shen Y.-Y., Liu J., Irwin D. M. \& Zhang Y.-P., 2010: Parallel and convergent evolution of the dim-light vision gene RH1 in bats (Order: Chiroptera). Public Library of Science One, 5(1: e8838): 1-9.

Souman J. L., Tinga A. M., te Pas S. F., van Ee R. \& Vlaskamp B. N. S., 2018: Acute alerting effects of light: a systematic literature review. Behavioural Brain Research, 337: 228-239.

StandRING K. (ed.), 2009: Prespa Walking Guide. Society for the Protection of Prespa, Agios Germanos, 203 pp +4 maps.

Stone E. L., Jones G. \& Harris S., 2009: Street lighting disturbs commuting bats. Current Biology, 19: $1123-1127$.

Stone E. L., Harris S. \& Jones G., 2015: Impacts of artificial lighting on bats: a review of challenges and solutions. Mammalian Biology, 80: 213-219.

Strid A., Bergmeier E., Sakellarakis F.-N., Kazoglou Y., Vrahnakis M. \& Fotiadis G., 2017: Additions to the flora of the Prespa National Park, Greece. Phytologia Balcanica, 23: 207-269.

THÉou P., 2016: Putative predation of Miniopterus schreibersii (Vespertilionidae, Chiroptera) by Zamenis longissimus (Colubridae, Reptilia) in the Albanian National Park of Prespa Lakes. Mammalia, 80: 571-572.

Theou P., Loce E. \& Bego F., 2015a: New data on bats (Chiroptera) in the Albanian National park of Prespa lakes. Buletini i Shkencave Natyrore, 19: 79-98.

ThÉou P., Loce E. \& Đurovic M., 2015b: Results of the pioneer survey of potential bat hibernacula in Albania (2012-2015). Natura Sloveniae, 17: 25-39.

Uhrin M., HoráčEK I., Š́́bl J. \& Bego F., 1996: On the bats (Mammalia: Chiroptera) of Albania: survey of the recent records. Acta Societatis Zoologicae Bohemicae, 60: 63-71.

Uhrin M., Benda P., LuČAn R., Miková E., Rendoš M. \& HoráČEK I., 2014: Noteworthy bat records from Romania. Vespertilio, 17: 197-213. 
VEROVNIK R., FIŠER Ž. \& ZAKŠEK V., 2015: How to reduce the impact of artificial lighting on moths: a case study on cultural heritage sites in Slovenia. Journal for Nature Conservation, 28: 105-111.

Voigt C. C. \& Kingston T. (eds.), 2016: Bats in the Anthropocene: Conservation of Bats in a Changing World. Springer International Publishing, Cham, ix+606 pp.

Voigt C. C., Roeleke M., Marggraf L., Pētersons G. \& Voigt-Heucke S. L., 2017: Migratory bats respond to artificial green light with positive phototaxis. Public Library of Science One, 12(5: e0177748): 1-11.

Voigt C. C., Azam C., Dekker J., Ferguson J., Fritze M., Gazaryan S., Hölker F., Jones G., Leader N., Lewanzik D., Limpens H. J. G. A., Mathews F., Rydell J., Schofield H., Spoelstra K. \& Zagmajster M., 2018a: Guidelines for Consideration of Bats in Lighting Projects. EUROBATS Publication Series No. 8. UNEP/EUROBATS Secretariat, Bonn, Germany, 62 pp.

Voigt C. C., Rehnig K., Lindecke O. \& Pètersons G., 2018b: Migratory bats are attracted by red light but not by warm-white light: Implications for the protection of nocturnal migrants. Ecology and Evolution, 8: 9353-9361.

Vrahnakis M., Papadatou E. \& Kazoglou Y., 2010: Grasslands as bat-lands: evidence from Mount Varnous, Greece. Bulletin of the European Dry Grassland Group, 8: 7-9.

Zagmajster M., 2014: The influence of external lighting on bats. Pp.: 15-19. In: Mohar A., Zagmajster M., Verovinik R. \& Bolta Skaberne B. (eds.): Nature-friendlier Lighting of Objects of Cultural Heritage (Churches). Recommendations. Dark-Sky Slovenia, Ljubljana, 28 pp.

Zeale M. R., Bennitt E., Newson S. E., Packman C., Browne W. J., Harris S., Jones G. \& Stone E., 2016 : Mitigating the impact of bats in historic churches: the response of Natterer's bats Myotis nattereri to artificial roosts and deterrence. Public Library of Science One, 11(1: e0146782): 1-23. 